By Dr. Safa'a Ahmed

\title{
Postcolonialism and Foreignisation as a Translation Strategy: A New Perspective to the Arab Family Values in Translated English Films
}

\author{
By Dr. Safa'a Ahmed \\ Associate Professor of Interpreting and Translation \\ Faculty of Languages, MSA University
}

\begin{abstract}
The intricate relationship between translation and mass media is particularly evident in the light of globalization, where the Arab media has heavily relied on translated materials as globalised, 'modernized', up-to-date and almost ready-made sources for its contents. The present paper aims to investigate 'postcolonialism' and the use of 'foreignisation' as a translation strategy in mass media and explore the latter's role in introducing some foreignised family values and roles alien to the identity of Arab societies from a new multidisciplinary perspective. Therefore, it raises three questions. What is the role played by the translation of English films in mass media in introducing some foreignised values alien to the Arab families bonding and values? How can foreignisation, as a translation strategy suggested by postcolonialists to resist colonialism, contribute itself to viewers' conceptions or misconceptions of social reality? What do the Arab youths think of this role? This qualitative and quantitative study uses content analysis and comparison to analyse the content of an English film and its Arabic translation, and questionnaire. Also, some secondary data, represented in visual images taken from the film Mrs. Doubtfire and thought to add high value to the research discussion and conclusion, complements the primary data. It adopts a multidisciplinary approach based mainly on Niranjana's postcolonial translation theory and Gerbner's Cultivation Theory in mass communication; images are anlaysed using Multimodal Critical Discourse Analysis. My intention is, by no means, to apply the Cultivation Theory in order to measure the effect the repetitive exposure to TV has on family ties. It is rather to present new perspectives at the level of translation theorization, topic and the multidisciplinary approach adopted. The analysis and discussion of data and results reveal that contrary to what many postcolonial advocates claim that the translator should adopt a foreignisation strategy, it enhances colonialism, or neocolonialism, when used in the translation of English texts into Arabic, or into what they call the 'less hegemonic languages'. The translation strategy used and mass media, (traditionally represented in TV), have both challenged and undermined some of the Arab family values and roles.
\end{abstract}

Keywords: Foreignisation, post-colonial translation studies, Cultivation Theory, family bonding, translation of English films 


\section{List of Figures and Tables}

\section{Figures and Images}

Image 1: Setting the Table for Dinner

Image 2: Gender Role-shifting

Image 3: Empowerment of Women

Image 4: Role-shifting and Cooking

Image 5: Role-shifting and Dancing with the Broom

Graph 1: Respondents' Answers to Questions 1 and 2. Y (Yes) and N (No)

Graph 2: Respondents' Answers to Questions 3-4. F (Females) and M (Males)

Graph 3: Respondents' Answers to Questions 5-8. F (Females) and M (Males)

Graph 4: Respondents' suggestions for the open-ended question Tables

Table 1: Description of Sampling Status

Table 2:Shows Respondents' Answers to the First 4 Questions of the Questionnaire

Table 3:Shows Respondents' Answers to the Questions 5-8 of the Questionnaire

Table 4: Respondents' Suggestions for a Positive Translation Role

\section{Introduction}

Haviland (2002) argues that in the process of globalising socio-cultural, economic and political issues of society, among others, the current condition of human society changes and people adopt new traits, trends and technologies borrowed mainly from the West. 'Due to modern technology, modernization creates the changes in traditions and values. People are going to accept this because progress is both necessary and beneficial to society and the individual', explain Ibrahim et al. (2010:271). Under this assumed inevitability, change in society, in family bonding and values for instance, takes place. The intricate relationship between mass media and translation becomes quite evident here as the former depends on the viewers' repeated exposure to certain messages to achieve an intended goal, while the latter has provided the tool necessary to reach more multinational audience, particularly with the dazzling advancements in mass media and more recently social media. The 


\section{By Dr. Safa'a Ahmed}

problem is that in such a globalised, Westernized world, one needs to reconsider and reassess how translation theories and their use in mass media contribute to viewers' conceptions of social reality about family bonding and values from different and various perspectives. Adopting a new multidisciplinary approach based on postcolonial translation studies and the Cultivation Theory in mass communication, the present paper aims to investigate 'postcolonialism' and the use of 'foreignisation' as a translation strategy in mass media and explore the latter's role in introducing some foreignised family values and roles alien to the identity of Arab societies. It is a qualitative and quantitative study using content analysis and comparison to analyse the content of an English film (Mrs. Doubtfire) and its Arabic translation. The approach is based on Niranjana's postcolonial translation theory and Gerbner's Cultivation Theory in mass communication. My intention is, by no means, to apply the Cultivation Theory in order to measure the effect the repetitive exposure to TV has on family ties.

\subsection{Operational Definitions:}

\subsubsection{Foreignisation}

'Foreignisation', in my opinion, is an old, new term: old in its sense as a concept and new in the coinage of the term itself. It has its roots in the 2000 year-long archaic debate of translating word for word (literally) or sense for sense (freely), since Cicero. In 1813 Scleiermacher was concerned about the relation between the writer and the reader and how to be reflected in translation (cited in Munday 2016:47-48). He argues that 'Either the translator leaves the writer in peace as much as possible and moves the reader toward him, or he leaves the reader in peace as much as possible and moves the writer toward him' (1813/2012:49). To bring the reader to the writer means that the translator uses an 'alienating' effect, where the latter becomes faithful to the source text and culture and the reader feels he is reading a translated, rather than an original, text. While bringing the writer to the reader means that the translator uses a 'naturalizing' effect, where the translated text sounds like an original text adapted to the taste of the target language, culture and audience.

The two concepts 'alienation' and 'naturalization' were further taken up by many scholars later, like George Steiner and Walter Benjamins. Venuti, for instance, uses the terms 'foreignisation' and 'domestication' to correspond to Scleiemacher's 'alienation' and 'naturalization'. Venuti claims that the translator makes an illusion of transparency when he translates into a fluently read, i.e. domesticated, text and thus he becomes 'invisible': 
A translated text, whether prose or poetry, fiction or nonfiction, is judged acceptable by most publishers, reviewers and readers when it reads fluently, when the absence of any linguistic or stylistic peculiarities makes it seem transparent, giving the appearance that it reflects the foreign writer's personality or intention or the essential meaning of the foreign text - the appearance, in other words, that the translation is not in fact a translation, but the 'original'. (2008:1)

Whereas a foreignisation strategy leads to the visibility of the translator whose target text gives the impression of a translation instead of a text originally written in the target language. Venuti (ibid.:15-16) regards foreignising practices as a 'highly desirable.. strategic cultural intervention' with the aim to 'send the reader abroad' by making the target culture aware of those linguistic and cultural differences inherent in the foreign or source text.

\subsubsection{Family}

There is no consensus on the definition of a 'family'. The sociologist George Peter Murdock (1949), in a cross national study of families in about 250 societies, defines 'family' as 'a social group characterized by common residence, economic cooperation and reproduction' which includes 'adults of both sexes, at least two of whom maintain a socially approved sexual relationship, and one or more children, own or adopted, of the sexually cohabiting adults' (cited in Bauman2015). One part of the dilemma of defining a family arises from the categorization of families into many types, such as:

-Nuclear Family: two parents with their biological children living in one household.

-Reconstituted Family: two partners sharing parental duties for one or more children living in one household, but only one of them is the biological parent.

-Single-parent Family: one adult with one or more children living in one household.

-Extended Family: relatives such as uncles, aunts or grandparents reside permanently in the same household like those of the nuclear family.

Most sociologists have adopted this view to date. Today, extreme sociologists criticize this definition for being narrow because it excludes many groups of people who consider themselves as a family, such as reconstituted or step-families and same sex families, indeed additions which the Arab and Islamic societies do not accept. Also, with the rise of 


\section{By Dr. Safa'a Ahmed}

social media as a source, if not a main one, of knowledge for many people and shaping their social realities about and conceptions of the world, the social media attempts to present new definitions of a 'family' become quite serious. For example, CyperParent (2017) argues that there is no such thing as 'normal' particularly when discussing the true meaning of 'family':

Now more than ever before, it is important for people to understand that when it comes to what is a family, there is no such thing as normal. Every person, every child, every parent, every couple has a unique situation, and to try and define everyone in one black and white term would make no sense.

Arab definitions vary between those translated directly from the West and the ones introduced from a genuine Arab perspective, on the other hand. Hussein Rashwan (cited in Al-Qawasmi: n.d.; Trans.) defines a family as 'a group whose members are linked together by blood and marriage ties and lead one social life, a matter which results in having rights and duties such as raising and rearing children'. Views from the Islamic civilization are noteworthy in this regard. Ibn Kaldoun, (1332-1406), the renowned international scholar who pioneered and founded sociology, indicates that a man is made 'human' through socialization where he gets to know and learn types of behaviour regulated and controlled by the standards of customs and traditions; only then he becomes a human (ibid.). Ibn Sina (980-1037), the well-known philosopher and physician, mentions that a human being differs from an animal in that the animal life is instinctive while human life varies and so do his crafts, food, drinks, clothes, needs. Therefore, individuals should co-operate in order to meet those needs and their skills and competences should vary; thus social normalization becomes a must to preserve the human species (ibid.). The Imam Al Ghazali, one of the most famous scholars, philologist and philosophers (1058-1111) of his age too, refers to the family's role in the socialization process of its children. This means polishing the individual's potentials, skills and tendencies at home first. Children acquire their characteristics through imitation and simulation (ibid.).

\subsubsection{Values and Family Bonding}

Values are fundamental to the good, acceptable and desirable working of societies. Leslie, Larson and Gorman (1994) say 'Values are group conceptions of the relative desirability of things'. Johnson (2013) uses the term to refer to general standards and 'higher order norms'. Similarly scholars like Haralambos (2000) and Mondal (2018) define a value as 'a belief that something is good and worthwhile. It defines what is worth having and worth striving'. 'Values are general conceptions of 'the good', 
Postcolonialism and Foreignisation as a Translation Strategy: A New

Perspective to the Arab Family Values in Translated English Films

ideas about the kind of ends that people should pursue throughout their lives and throughout the many different activities in which they engage', adds Worsley (1970).

Horowitz (2005:2-7) considers the family as a bridge connecting the individual's 'micro-world' to the 'micro-world' of the bigger economic society, hence the family's essential function is to educate children of social norms required to integrate into the society. The economist and political philosopher F.A. Hayek presumes that 'Part of our present difficulty is that we must constantly adjust our lives, our thoughts and our emotions, in order to live simultaneously within different kinds of orders according to different rules.. So we must learn to live in two sorts of worlds at once' (cited in Bartley1989:18).

'Family bonding' is a value necessary for a healthy society. Family life, Moufeed (2015) and Al-Qawasmi (n.d.; Trans.) argue, is a group of relations, functions and interactions where every member has a role to play in the integration of the various family aspects. The results of the complex interactions between some biological, sociological and economic factors determine marriage ties. The stability of these ties depends largely on internal factors such as how family members respond to each other. Therefore, the less concurrence between the two partners, the less bonded the family becomes. Studies show that around $80 \%$ of juvenile delinquents come from houses dominated by disagreements and quarrels (ibid.). Glueck (1960) concludes that $70.4 \%$ of juvenile delinquents in the United States were raised in families where continuous quarrels exist between parents or between parents and their children. Recent statistics do not differ a lot. Parks (2013:34) also found out that 'adolescents from cohabitating families have a greater odds of engaging in nonviolent delinquency compared to those from two biological-parent families, although reaching only marginal significance'.

\subsection{Review of the Literature}

Developments in globalization and cultural identity research sparked a new translation trend, postcolonial translation studies (Naude2012), which started in the 1990 s by scholars whose primary concern was to examine the consequences of translating Third World literature into the hegemonic languages of previous colonizers, principally English (Munday2016). These studies aspire to reclaim and rewrite the marginalized nations' histories, deformed and dehistoricized by orientalist discourse, and literary traditions for postcolonial societies. Goff (2014:122) says that postcolonial translation may also 'refer to works of 


\section{By Dr. Safa'a Ahmed}

opposition or resistance produced under colonialism.. (they) can also include resistance to neo-colonialism'.

The translation of Indian literature into English, for instance, has misrepresented India's identities and enforced a colonial agenda. Despite its long history and civilization, the orientalist discourse focussed mainly on the Sanskrit language and the Vedic Hindu religion and represented both as monolithic categories to form India's identities. Therefore, Ashcroft, Griffiths and Tiffin (1989) argue that post-colonial writings replace the language of the centre with a discourse fully adapted to the colonized culture. Trivedi (2003) uses the term 'politics of domination and neo-colonialism' in the post-colonial discourse originally formulated in the West to show ironically how the Third World relies on the West for approval.

In postcolonial India, literary production, whether Indian writing in English or English translation of local language writing, has employed the subversive and self-assertive politics of abrogation and appropriation. 'Abrogation' refers to the 'refusal of the notion of the correctness of usage, fixed meanings and assumptions dictated by the categories of imperial culture', while 'Appropriation' to 'the process by which English is adopted and adapted to express cultural experiences which are very different from imperial ones' (Holmstrom1997:4). Appropriation of English means Indianizing it by maintaining speech rhythms and movement of the local languages, retaining words from Sanskrit and regional languages for concepts, rituals, kinship terms and forms of address and replicating mythological and literary references.

Garane (2014) stresses in his article 'How Postcolonial Translation Theory Transforms Francophone African Studies' and so does Basu (2014) in 'Postcolonial World Literature', that studies of translating Indian and Francophone literature reveal how the original message is twisted to present an ideal image of the colonizer vs. the colonized's. Translation in the opinion of postcolonial scholars, like Pettersson's (1999) 'The Postcolonial Turn in Literary Translation Studies', has become a destructive tool deforming original texts. Leung (2006) also approaches the idea of the ideological turn in translation studies and Naude (2012) talks about the shaping of cultural knowledge through South African translation.

Niranjana (1992) assumes that the translator should mediate through translation to prevent the exercise of colonial powers in target discourse. In her book 'Siting Translation: History, Post-Structuralism, and the Colonial Context' (1992), she investigates colonial history and poststructuralist theory to exemplify the unequal power relationship between the colonizer and colonized's cultures found in the translated 


\section{Postcolonialism and Foreignisation as a Translation Strategy: A New}

\section{Perspective to the Arab Family Values in Translated English Films}

works. Her contribution to the field of postcolonial translation studies is quite significant; the theory and opinions are discussed in more details in the theoretical part of the present paper.

According to the postcolonial studies, the translator should 'foreignise' artifices concerning material culture, social structures, knowledge of the world, linguistic properties to make the 'different' poetics and literary discourse of the once-colonized nation appreciated. In so doing, he uses untranslated words in his translations and includes unfamiliar cultural material, which are not considered necessarily as defects of the translated texts. Instead, this brings about cultural expansion that enriches the postcolonial world. Some radical translators and theories move a step further and call for a full negation of interpretative facilitators such as glossaries, footnotes, paraphrasing and even italics as an apparent expression of subversion and reconsideration of colonial hegemony. In translations from minority to dominant cultures, those postcolonial theorists and translators assert the importance of using foreignisation as a translation strategy and of ignoring such facilitators to suppress postcolonial hegemony.

Palakeel (1996) indicates that in reality, much of the Third World literature that transmigrates into First World languages is selected just for its political, ethnographic and anthropological character rather than for any intrinsic literary merit. Today there is a general though somewhat grudging consensus amongst postcolonial writers and theorists that the empire can and should translate back only in an increasingly defamiliarized English if not in the hegemonic English of the colonial masters (Ashcroft, Griffiths and Tiffin1989).

A tremendous work has been done in postcolonial translation studies. However, Sakellariou (2011) indicates that there is no consensus on how to address such cultural issues in translation studies. Bhabha (1994) and Trivedi (2005), for instance, are worried that the new discipline can devoid the translation discipline of its systematic processes. Yet, Zaixi and $\mathrm{Lu}$ (2007) presume that postcolonial studies can enhance deeper levels of analyses so long as the central position of translation remains untouched. Concerns of representation, homogeneity and hegemony are raised. Indeed some criticisms go as far as claiming that postcolonialists are managing a postcolonial agenda.

From this review of the literature, it seems that most postcolonial translation studies address literary works, i.e. they tackle the postcolonial effect of translating works from what they call a 'marginal language' into a 'hegemonic' one, not vice versa. That is to say, they do not investigate 
the postcolonial implications for translating globalised works, films for instance, on the identity and values of the Third world nations using foreignisation as a translation strategy. There is also a gap in addressing postcolonial effects of translation in mass media from the perspective of both translation studies and mass communication theories. There is a lack in the studies regarding the probable effects of using 'foreignisation' on family bonding.

\subsection{Significance of the Study}

The significance of the present paper arises from the novelty of the topic and how it is approached. The role translation plays in mass media and its impacts for family values are vital for the understanding of the changes taking place in the Arab societies and their identity. The multidisciplinarity of the perspective employed would hopefully give the reader an insight into the issue at hand from a newly different angle. Also the researcher presents a translation theorization from an Arab point of view and looks at postcolonial translation studies from a critical rather than a suspicious stand, although she claims to be a postcolonialist scholar herself. Hence, she suggests to redefine postcolonial translation studies and reconsider those theories.

In addition to this introduction, the paper is divided into three main sections. The first one presents the theoretical framework on which the study is based. The methodology is elaborated in the second section. The third section tackles the results, the analysis and discussion of data.

\section{Theoretical Framework}

Since this paper investigates foreignisation from a multidisciplinary perspective, the following theoretical framework is divided into a part tackling the post-colonial translation tenets as proposed by Niranjana and another explaining Gerbner's Cultivation Theory. A final part is dedicated to MCDA Analysis.

\subsection{Niranjana's Siting Translation}

In her book Siting Translation (1992), Tejaswini Niranjana, a postcolonial theorist, bases her translation theory on three translations of the Sanskrit vacana, an extract from a Southern India spiritual text written in the twelfth century, and Jacque Derrida and Walter Benjamin's views on translation. She explores in detail the works of Paul de Man and Derrida, two major poststructuralist, and their dialogues with Benjamin and questions translation norms like 'authenticity', 'fidelity' and 'repetition'. She discusses the potential of translation as a strategy of resistance. Niranjana gives examples from post-colonial contexts to 
Postcolonialism and Foreignisation as a Translation Strategy: A New

Perspective to the Arab Family Values in Translated English Films

reveal how translation was a technology of colonial domination. For instance, colonial powers used translation as an imperialist tool to codify Hindu law and to create a subject position for the colonized' which would 'discipline and regulate the lives of' Hindu subjects. The notion of 'original' text was used to modify, in fact to deform, the native's image and erase his identity.

Critics like Gayatri Spivak (2012) asserts, in his essay The Politics of Translation, the existence of 'a scrupulously visible political agenda'. Similarly, Niranjana assumes that postcolonialists will be able to 'reinvent oppositional cultures in non-essentializing ways' (cited in Gopal1993:204). Consequently, translation is more than an interlingual process so long as it determines the functioning of whole disciplines such as ethnography. The translator's task, borrowing Walter Benjamin's phrase, is 'to invent rather than represent, to privilege a political model over an epistemological or even a poetical one' (ibid.:205).This means approaching the text from a partially political perspective while considering poststructuralist insights too. Gopal mentions that 'Niranjana's theory is characterized by a willingness to read texts against the grain? critiquing the politically unviable while appropriating the usefully radical modes of deconstructing hegemonic discourses' (ibid.).

Influenced by Venuti (2008)'s concept of 'foreignisation' and 'invisibility' of the translator, Niranjana suggests a foreignisation strategy incorporating elements of the original in the target text. She analyses two translations of a vacana and attributes their failure to the inclusion of Western terms typically used by the nineteenth century missionaries and Anglo-Indian commentators (Milton2008: 103-4). Therefore, she recommends retranslating Indian literature free from such 'pseudoChristian values'. Niranjana also urges translators to leave proper names untouched, i.e. calque them as they are in the original. Furthermore, she attacks domesticating the translation, or 'homogenizing and continuous narratives' (Niranjana1992:185). She asks Venuti, a postcolonial, to reveal 'hegemonic representations of the non-Western world' (ibid.:186). According to this point of view, translators should mediate to introduce heterogeneity, overlook the idea of purity and show instead that origins are not monolithic; translation should become a 'disruptive and disseminating force' (Milton 2008:104).

Yet, there is a number of criticisms against Niranjana's suggested translation strategy. The supremacy of word over text overlooks the need of the translator 'to treat language, poetry and translation as processes which have multiple levels that cannot be collapsed onto each other' 


\section{By Dr. Safa'a Ahmed}

(Dharwadker1999:126). Also the inclusion of foreign elements from the original into the target does not give due attention to the reader or the audience (Milton2013:105). The idea of giving attention to the reader raises the issue of transparency in translation and how the translator becomes invisible so the target text reads like an original, not a translation. Foreignisation does not allow this kind of transparency.

Robinson also criticizes Niranjana for following Benjamin's rules of literalism and foreignisation since 'the potential for creative retranslation is somewhat impoverished, largely because she has found or developed no local models for such creativity' (1997a:158, cited in Milton2008:1056). He mentions that such translations are a kind of 'holding back from communication', which would doubtfully lead to a decolonialised effect on societies; stated simply, to have an effect, you should basically 'communicate' first (ibid.). Then he wonders how a foreignised translation can appeal to and push readers to act in a certain way or resist colonialism; this thinking has no reasoning. He explains that 'The fact is, the assumption that a phrase has to be alien to startle us into an awareness of alterity is grounded in a naïve realistic epistemology according to which old (or realistic, or familiar) information is always ground and new (or fantastic, or alien) information is always figured' (Robinson1997b:95). I totally agree with him particularly because this translation strategy results in a 'childish, primitive' target text, a reaction which postcolonialism should counteract instead.

\subsection{Gerbner's Cultivation Theory}

Though George Gerbner conceptualized the Cultivation Theory in the 1960 s and 1970s, it seems to have survived through continuous adjustment and refinement. Since 2000, Eman Mosharafa (2015:22) argues, over 125 studies have endorsed the theory, which reflects its ability to adapt to the constantly changing nature of media environment. The Cultivation Theory explores the long-term effects of watching television on viewers. It postulates that the TV danger lies in its great ability to shape people's values, morals and general beliefs about the world.

Symbolic environment, storytelling, TV symbolic function, and TV traits are basic tenets in the theory Mosharafa (2015:23-4). First, humans are creatures who live beyond their immediate environment threats and gratifications and they learn from stories, not necessarily from personal experiences. Second, there are three types of story-telling which form culture according to Gerbner (2002): fictional stories about 'how things work' revealing in that way the various dynamics of human life; news stories about 'how things are' assuring the society's rules and norms; and other stories about 'what to do' showing values and choices or behaviours. 


\section{Postcolonialism and Foreignisation as a Translation Strategy: A New}

\section{Perspective to the Arab Family Values in Translated English Films}

Third, the symbolic function of TV is presenting knowledge about life, people, society and state authority i.e. it disseminates values and morals in an acceptable and enjoyable manner. Gerbner explains that the accumulated exposure to TV results in cultivation, a kind of desultory learning. Whatever content the viewer sees, then, on the screen constitutes his basic mental image about the world. Gerbner adds that films and series may leave a cultural impact far exceeding that of the serious programmes, studies or seminars and the idea that news is information while entertainment is not is a fallacy. In other words, films can shape the viewer's knowledge and image about the world as much as news or serious materials do, and here is exactly where the main assumptions of the present paper lie.

Therefore, depending on TV, or mass media generally, to form conceptions of masses may become dangerous. Gerbner thinks that 'there seems to be a risk in having the masses dependent on media means, especially $\mathrm{TV}$, in constructing the image of the surrounding environment' and that 'the media may present untruthful information, distorted stereotypes or misguided positive images' causing recipients' perceptions to be stereotyped and distorted (Mosharafa 2015:24-6). Television in Gerbner's opinion does not eventually reflect what is taking place in the outside world, instead it presents an artificial world that stresses certain issues according to the will and interests of those controlling the media. The accumulated exposure to TV and the lack of personal experience in many matters help create this artificial world, which becomes gradually more and more real to the viewers. Finally, TV is persuasive, accessible and coherent. Research shows that heavy TV viewers share similar perceptions of cultural and social issues while light viewers do not or have a distorted image for them. For instance, repeated exposure to romantic media materials creates an idealized image of marriage, in the viewers' minds, contrary to reality, and the contrast between reality vs. expectations becomes quite evident.

The Cultivation Theory is criticized for exaggerating the effect of TV on people suggesting that the 'entire' value system is shaped to a great extent by TV. It is true that TV influences ideologies, values, images, socially proper conduct, etc. but still there are other factors involved especially nowadays, i.e. scholars may disagree on the degree of the effect but they agree on the significance of the effect itself.

\subsection{Multimodal CDA}

Wodak and Meyer (2001:2) demonstrate that Critical Discourse Analysis (CDA) handles discourses which 'testify to more or less overt relations of 


\section{By Dr. Safa'a Ahmed}

struggle and conflict'; this means that language shapes and is shaped by society. CDA, linguistically-oriented for a long time, started to consider visual images and broader multimodal concepts in the nineties (Machin2007; Kress and van Leeuven1996). Mayr (2012) states that Multimodal Critical Discourse Analysis (MCDA) is probably 'the most comprehensive attempt to develop a theory of the inter-connectedness of discourse, power and ideology'. This notion is based on Halliday's theory (1978) that discourse consists of many linguistic and non-linguistic forms of representation. Visual structures, such as images, diagrams, graphics and photographs, convey ideological meanings to the recipients.

To investigate the text-sender's choices of linguistic and visual features in language, van Leeuven (1996) developed tools, inspired from Systemic Functional Linguistics (SFL). Social actor analysis is one of these tools and it is 'a linguistic and visual inventory of the way we can describe and classify people and some of the ideological effects that these classifications can have' (Mayr 2012). Thus, people are personalized or impersonalized. Some strategies, like naming for instance, are employed to foreground or background certain aspects of their identity.

Despite the great successes of the MDCA approach in the analysis of images, O'Halloran (2012:445) criticizes the limitations inherent in the model. It fails to model the functionality and grammars for non-linguistic features, such as visual images, movement and gesture, sounds and music, etc. It cannot map the metafunctions of the semiotic flow in written texts. The analysts could not integrate theories from other disciplines into their analyses. Until now, software applications are lacking.

\section{Methodology}

Living in a world that tries hard to globalise, or more accurately Westernise, values and identities, how translation and mass media can contribute to viewers' misconceptions of and assumptions about social reality needs recosideration. Hence upon, the present paper investigates 'postcolonialism' and the use of 'foreignisation' as a translation strategy in mass media and explores the latter's role in introducing some foreignised family values and roles alien to the identity of Arab societies.

To this end, the study raises three questions:

1-What is the role played by the translation of English films in mass media in introducing some foreignised values alien to the Arab families bonding and values?

2-How can foreignisation as a translation strategy suggested by postcolonialists to resist colonialism, contribute to viewers' conceptions or misconceptions of social reality?

3- What do the Arab youths think of this role? 
Postcolonialism and Foreignisation as a Translation Strategy: A New

Perspective to the Arab Family Values in Translated English Films

In order to answer these questions, it sets the following objectives:

1-To review the literature with a view to identify the gap in understanding foreignisation and the role translation plays in mass media and its relationship with family values and bonding;

2-To collect some representative data from an English film and its Arabic subtitled translation;

3-To analyse the content of the English ST and its corresponding TT and have a profile for each, using a postcolonial approach, then compare to assess the translator's strategy;

4-To analyse and compare, using the Cultivation Theory approach, the messages' potentially negative impacts on family values and bonding;

5-To make a questionnaire, then reveal and discuss results;

6-To establish relationships to assess the contribution of film translation to viewers' conceptions of social reality, especially family values and bonding;

7-To assess foreignisation as a translation strategy introduced by postcolonialists with an alleged aim of resisting colonialism; and 8-To make recommendations in this regard.

This is a qualitative and quantitative study whose research tools are mainly content analysis and comparison. The data consists of samples extracted from an English film and its Arabic rendering, few images, as well as a questionnaire. The film 'Mrs. Doubtfire' (1993) is chosen for the theoretical qualitative analysis for its rich direct and indirect references to family values and relationships. 'Mrs. Doubtfire' is a modern comedy classic based on 'Alias Madame Doubtfire' novel by Anne Fine. It is directed by Chris Columbus, written for the screen by Randi Mayem and Leslie Dixon and starred by Robin Williams (Daniel Hillard) and Sally Field (Miranda). The storyline tracks a divorce in a family of a successful interior designer (Miranda), an unemployed voice actor (Daniel) and their three children Lydia (Lisa Jakub), Chris (Mathew Lawrence) and the 5year-old Natalie (Mara Wilson). Miranda starts the proceedings of divorce. Daniel is permitted a visitation to see his children only once a week. The desperate loving father who wants to stay with his children, dresses up like a lady, pretends to be Mrs. Doubtfire, an imaginary British housekeeper, and wears a prosthetic mask. The events flow uninterruptedly and smoothly until the goal of divorce is attained.

On the other hand, a sample of 50 students at MSA University fill in a questionnaire (check the Appendix) for the quantitative part of the research. The sample (41 females and 9 males; between the age 20 and 21 ) is picked randomly out of a total population of 100 fourth-year 


\section{By Dr. Safa'a Ahmed}

students at the Faculty of Languages. They all have studied translation courses and theories for about 3-3.5 years. Thus, the population may be said to be representative and would hopefully lead to valid and reliable results.

Table 1: Description of Sampling Status

\begin{tabular}{|l|l|l|}
\hline Gender & Age & $\begin{array}{l}\text { Status of } \\
\text { Sampling }\end{array}$ \\
\hline Females & $20-21$ & 41 \\
\hline Males & $20-21$ & 9 \\
\hline
\end{tabular}

The questionnaire consists of 9 questions. 2 questions are yes-or-no questions asking whether the translation of English films has brought about foreignised values alien to the Arab family and whether this negatively affects family relationships, or not. 6 questions are about the degree of agreement or disagreement to the statements that such a translation has helped undermine family values and relationships. One open-ended question asks students to write their suggestions on how mass media translation can play a positive role in making family ties stronger.

It is also necessary to talk about the integration of visual images to the analysis. Few images are carefully selected from the film and analysed to further enrich and enhance the discussion.

The paper investigates the issue at hand from a new multidisciplinary approach derived mainly from postcolonial translation studies and the Cultivation Theory in mass communication as explained in section 2. My intention is, by no means, to apply the Cultivation Theory in order to measure the effect the repetitive exposure to TV has on family ties. And of the four steps suggested by Gerbner, I applied only those appropriate for the aim of the study. I analyse the content of the message, take people's views about the world (through the questionnaire) and establish relationships between the exposure to such messages, their impact for family values and the probable reactions of viewers. Meanwhile, I exclude an assessment of exposure time for its irrelevance.

The rationale behind the division of data analysis and discussion section is to investigate family bonding and how values may change across the different relationships between the various family members, in a way that makes it easy to integrate the three types of data used (the qualitative, the quantitative and visual images). Thus, the sub-sections cover family bonding, and the wife-husband and husband-wife, parentkids, parent-kids and kids-kids relationships and roles. Despite the richness of the analysis, I am aware of the limitations of the study. The 


\section{Postcolonialism and Foreignisation as a Translation Strategy: A New Perspective to the Arab Family Values in Translated English Films}

type and size of data represent the major limitation here. The questionnaire sample could have been bigger and its representativeness may be questioned, for example would young generations from poor or marginalized regions have the same opinions? Alike, adopting other perspectives can enhance the reliability and validity of the results and drawn conclusions.

\section{Data Analysis and Discussion}

First, the results of the questions are shown in the next tables and figures:

Table 2: Shows Respondents' Answers to the First 4 Questions of the Questionnaire

\begin{tabular}{|c|c|c|c|c|c|c|c|c|c|c|c|c|c|c|}
\hline \multirow{2}{*}{$\begin{array}{c}41 \\
\text { Females }\end{array}$} & \multicolumn{2}{|c|}{ Q1 } & \multicolumn{2}{|c|}{ Q2 } & \multicolumn{5}{|c|}{ Q3 } & \multicolumn{4}{|c|}{$\mathrm{Q} 4$} & \\
\hline & $\mathrm{Y}$ & $\mathrm{N}$ & $\mathrm{Y}$ & $\mathrm{N}$ & 1 & 2 & 3 & 4 & 5 & 1 & 2 & 3 & 4 & 5 \\
\hline 9 Males & & & & & & & & & & & & & & \\
\hline $\mathrm{F}$ & 40 & 1 & 27 & 14 & 0 & 19 & 20 & 2 & 0 & 6 & 19 & 12 & 2 & \\
\hline M & 9 & 0 & 3 & 6 & 0 & 2 & 6 & 1 & 0 & 1 & 2 & 2 & 3 & 1 \\
\hline
\end{tabular}

(Disagree) and 5 (Strongly Disagree)

Table 3: Shows Respondents' Answers to the Questions 5- 8 of the Questionnaire

\begin{tabular}{|c|c|c|c|c|c|c|c|c|c|c|c|c|c|c|c|c|c|c|c|c|}
\hline & \multicolumn{5}{|c|}{ Q5 } & \multicolumn{5}{|c|}{ Q6 } & \multicolumn{5}{|c|}{ Q7 } & \multicolumn{5}{|c|}{ Q8 } \\
\hline $\begin{array}{c}\text { Females } \\
\text { 9 Males } \\
\end{array}$ & 1 & 2 & 3 & 4 & 5 & 1 & 2 & 3 & 4 & 5 & 1 & 2 & 3 & 4 & 5 & 1 & 2 & 3 & 4 & 5 \\
\hline $\mathrm{E}$ & 5 & $\begin{array}{l}1 \\
5\end{array}$ & 1 & 5 & 0 & 1 & 1 & 1 & 1 & 2 & 6 & $\begin{array}{l}2 \\
3\end{array}$ & 7 & 5 & 0 & & $\begin{array}{l}1 \\
8\end{array}$ & 9 & 3 & 1 \\
\hline VII & 0 & 3 & 1 & 4 & 1 & 1 & 2 & 2 & 1 & 3 & 0 & 7 & 0 & 2 & 0 & 3 & 2 & 2 & 2 & 0 \\
\hline
\end{tabular}

F (Female), M (Male), 1 (Strongly Agree), 2 (Agree), 3 (Neutral), 4 (Disagree) and 5 (Strongly Disagree) 


\section{By Dr. Safa'a Ahmed}

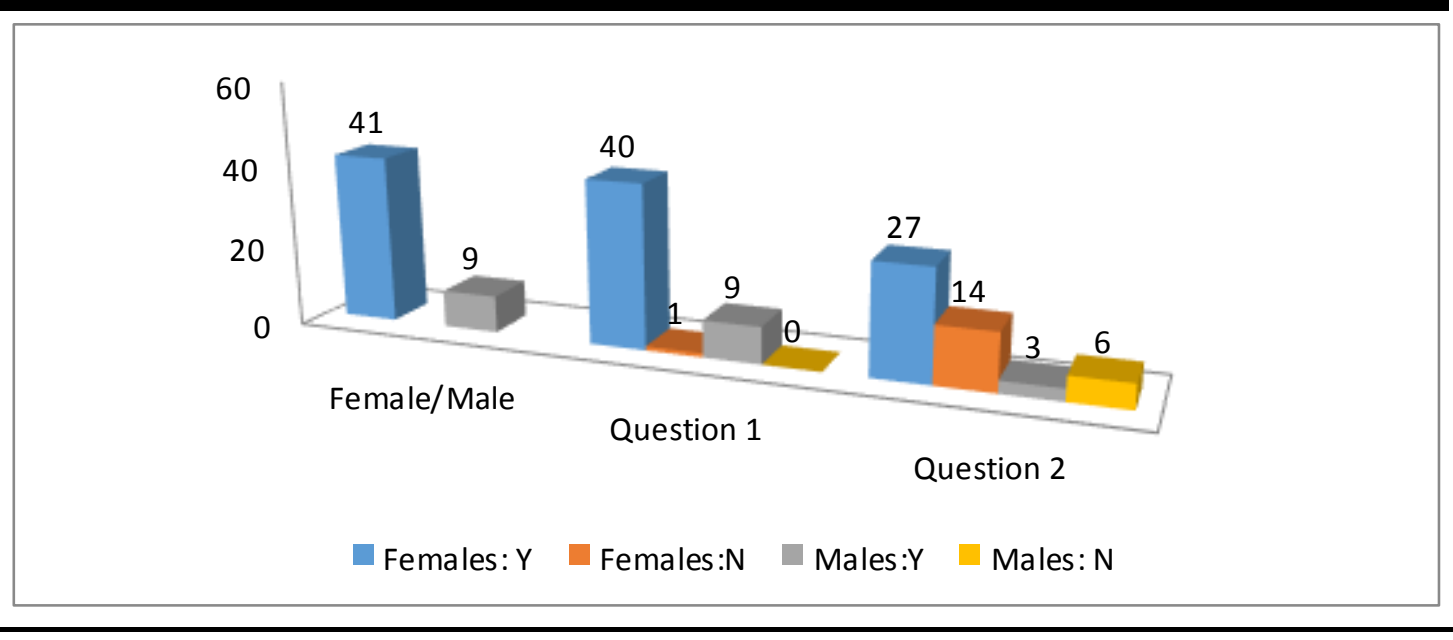

Graph 1: Respondents' Answers to Questions 1 and 2. Y (Yes) and N (No)

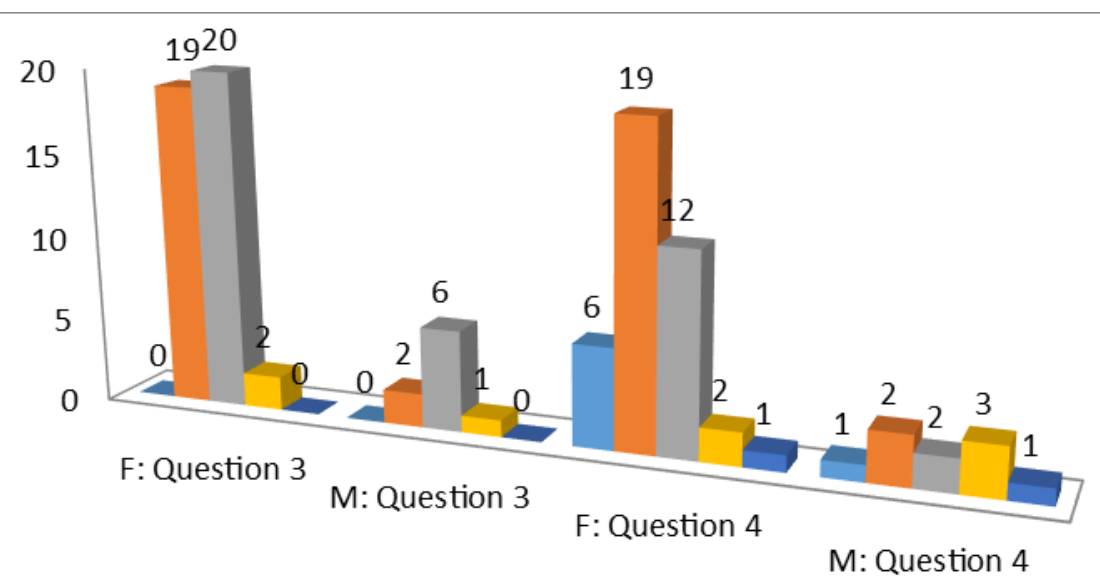

Strongly Agree $\square$ Agree $\square$ Neutral Disagree $\square$ Strongly Disagree

Graph 2: Respondents' Answers to Questions 3-4. F (Females) and M (Males) 


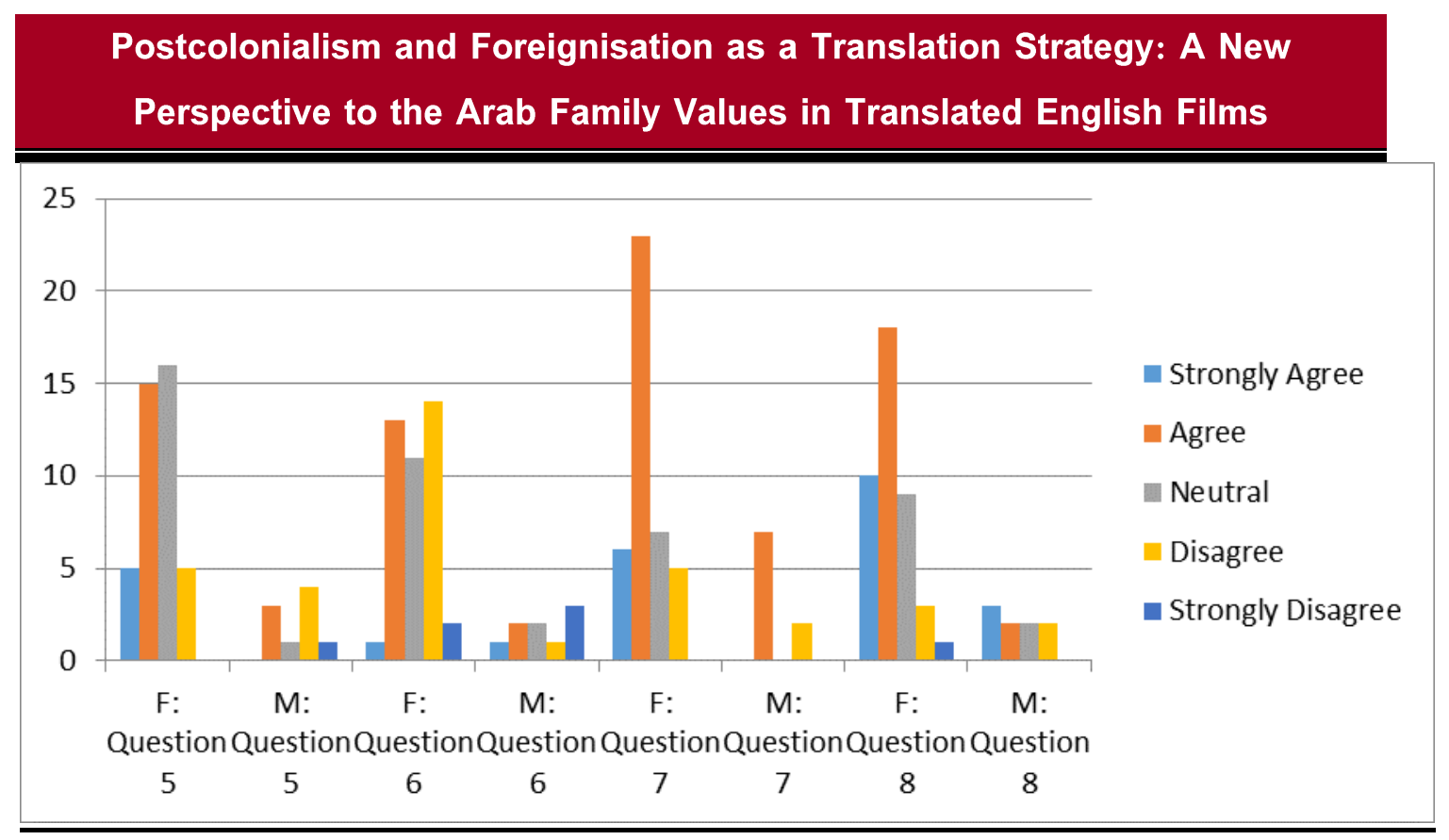

Graph 3: Respondents' Answers to Questions 5-8. F (Females) and M (Males)

Table 4: Respondents' Suggestions for a Positive Translation Role

\begin{tabular}{|l|l|}
\hline \multicolumn{1}{|c|}{ Respondents' Suggestions } & Number \\
\hline $\begin{array}{l}\text { Avoid translating films negatively affecting Arab } \\
\text { culture }\end{array}$ & 19 \\
\hline Avoid translating curse or negative words & 5 \\
\hline Translate using domestication & 2 \\
\hline It is not the translator's role & 3 \\
\hline Families are to blame & 2 \\
\hline Translation introduces good foreign culture & 4 \\
\hline Translation is both positive and negative & 3 \\
\hline Translators should be honest & 2 \\
\hline When mass media becomes a model & 1 \\
\hline Irrelevant response & 6 \\
\hline No comment & 3 \\
\hline Total & 50 \\
\hline
\end{tabular}




\section{By Dr. Safa'a Ahmed}

\section{Respondents' Suggestions}

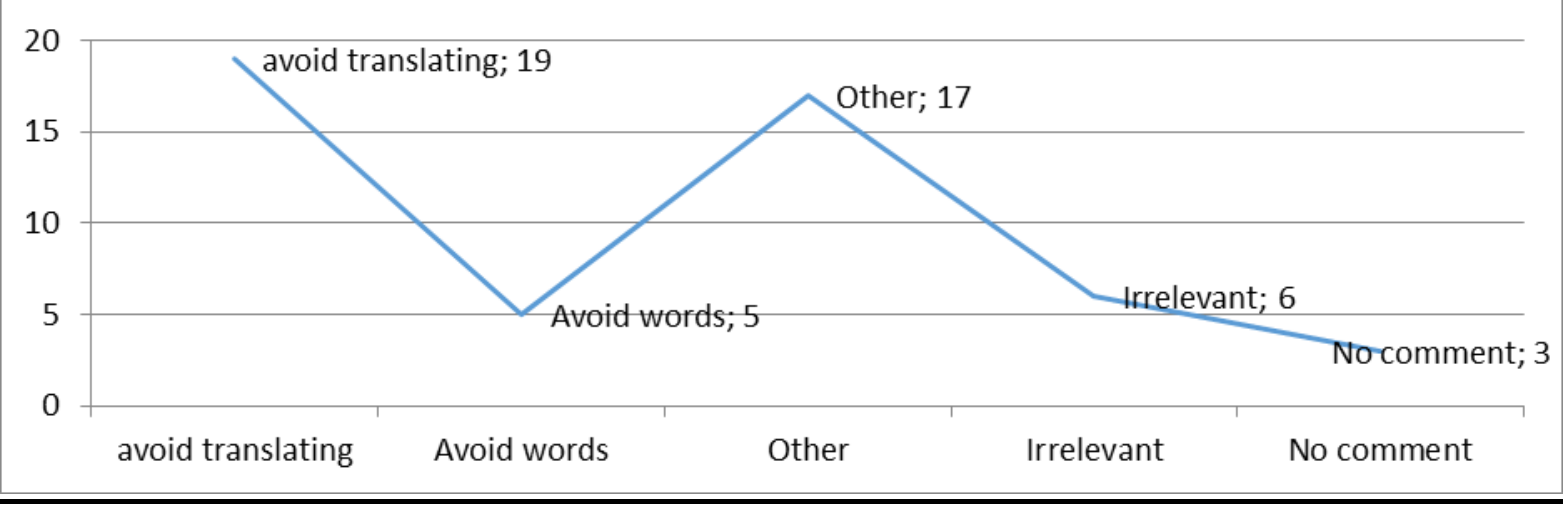

Graph 4: Respondents' suggestions for the open-ended question

'Mrs. Doubtfire' talks about three pivotal themes: 'family', gender and sex or role-shifting, and divorce. Through these themes, some values are approached.

\subsection{Family Bonding}

Family bonding suffers from severe problems from the beginning of the film. The wife, an empowered successful designer, seems to be dissatisfied with her marriage. She reaches the conclusion that she should get divorce, telling Daniel, her husband, 'It's over' in example [1]:

[1]-Miranda: It's over!

\section{It's over.}

Come on, Miranda. We've got problems,--Daniel:

but who doesn't? We could work 'em out.

-Miranda: We've been trying to work them out

For 14 years.

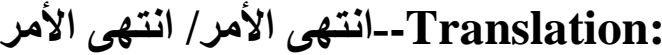

ـ هيا يا مير اندا، لدينا مشاكل و هذا/ شأن الجميع، بوسعنا العمل على حلها

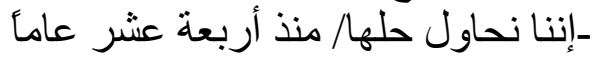

The translation is so direct that the expression 'come on' is rendered into the target language word-for word. Such a foreignised translation strategy presents not only an awkward target structure, which is strange to the Arabic tongue in this context, but also a way of life of how a powerful woman has decided to end the marital relation and break family bonding without probably trying hard enough. Daniel proposes to consult a family therapist or to go on vacation in an attempt to rebound the family, but it seems too late for Mirada? this is equivalent to the traditional Islamic 
Postcolonialism and Foreignisation as a Translation Strategy: A New

Perspective to the Arab Family Values in Translated English Films

and Arab concept of bringing a mediator from his family and a mediator from hers with a view to reach a solution or a judgment.

Miranda argues that 'We're different' is a good reason for a husband and wife to get divorced, despite the love that one of the two parties may still have towards the other:

[2]-Miranda: We've just grown apart. We're different.

We have nothing in common.

-Daniel: Oh, sure we do. We love each other...

-Miranda: I want a divorce.

-Daniel: No./ We can't. We're a family. You know?

ـلقد اتسعت الفجوة بينناء/ نحن مختلفان/ لا شيء يجمعنا

-Translation:

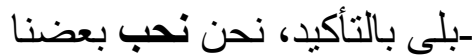

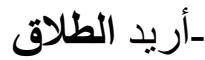

- الا بمكننا ذلك، نحن عائلة

The translator continued his foreignisation strategy. With the exception of the filler 'You know', almost every expression in the source text, example [2], has a communicative equivalence in the target text, using Newmark (1981)'s term. Here Daniel refers to the concept of the nuclear family, whose bond must be maintained by being together, i.e. no divorce. The film moves the message-receivers implicitly but gradually from the concept of 'family' as such towards a totally different concept in the end. Hence comes the danger of the manipulative creepy ways through which mass media delivers foreignised values.

Mocking at step-mothers undermines the relationship of family members with grand-parents. In a touching dialogue between the father who is bidding his children farewell and leaving the family 'house' (a cornerstone in traditional 'family'), the five-year-old Natalie tells her father innocently that he can't go now because 'We're in the middle of Charlotte's Web (a story)'. 'Grandma would finish it for you', he says; but she does not like this idea for a number of reasons, amongst them is that granny 'smells funny too'. Then he makes fun of the latter indicating that it is the smell of formaldehyde in which she is preserved:

[3]-Natalie: She smells funny, too.

-Daniel: That's the formaldehyde./That's why Granny's so well

كما أن رائحتها كريهة أيضاً

preserved.

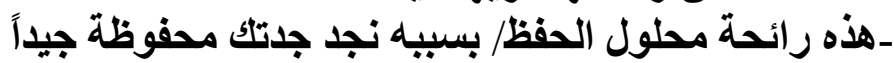

The target text is not only literally translated but also very weak. For instance, 'too' is translated twice (as 'also' and 'too'). The translation of 
'that's why Granny..' is weakly structured into 'because of it, we find..'. Again, the traditional Arab culture highly respected grandparents. I do not argue, however, that watching the film is the reason why this value has diminished somehow. I just assume, according to the Cultivation Theory, that the repeated exposure to similar mass media messages helps introduce and highlight foreignised or unfamiliar values.

The main message, the theme of divorce and family, is finally crystallized at the end of the film. Daniel as Mrs. Doubtfire, in a famous programme for children, reads a letter sent by a sad child whose parents are divorced and who asks 'Did I lose my family?' and wonders 'Is there anything I could do to get my parents back together?' Though his answer may give hope for divorced families, particularly children, that divorce is not the end of the world or of one's life, yet it provides a new foreignised or Westernized concept of 'family'. In example [4], the lovely Mrs. Doubtfire denies the concept of the nuclear family and replaces it with a fresh but shocking definition of a 'family' since 'there are all sorts of different families'.

[4]-Mrs. Doubtfire: There are all sorts of different families, Katie. Some families have one mommy, some families have one daddy, or two families. Some children live with their uncle or aunt. Some live with their grandparents, and some children live with foster

parents.

Some live in separate homes and neighborhoods in different areas of the country. They may not see each other for days, weeks, months or even years at a time. But if there's love, dear, those are the ties that bind.

And you'll have a family in your heart for ever. ـ ـهناك أنواع كثيرة/ من العائلات يا كيتي/

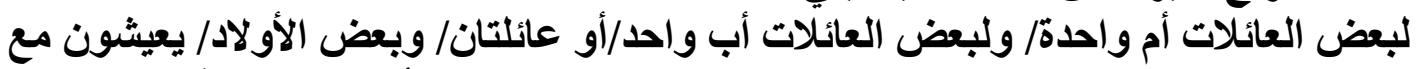

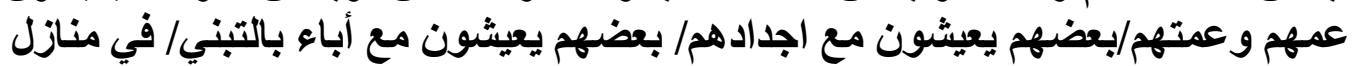

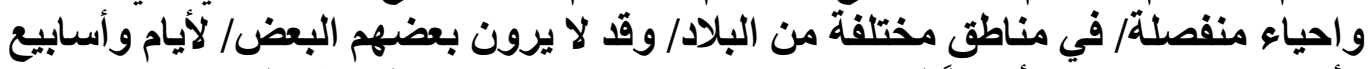

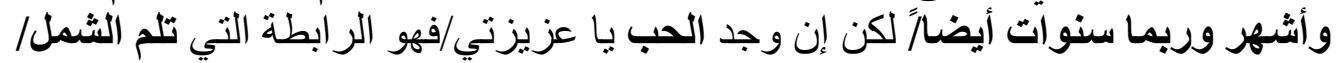
وستكون للك/ عائلة في قلبك إلى الأبدا إندا

In the Arab countries, there are understandably the one-parent family, the relative family or the family where the father is married to two wives living together in the same house constituting two families? I use the slant in example [4] to indicate the end of a line on the subtitling screen. But to introduce the idea of the foster family, living in separate homes and neighbourhoods, or not seeing each other even for years as acceptable normal types of 'families' represents a foreignised approach to 'family' 
Postcolonialism and Foreignisation as a Translation Strategy: A New

Perspective to the Arab Family Values in Translated English Films

according to the Arab culture. Due regard should be paid in the first place to the contraction of the physical definition of family into the abstract concept of having it just 'in your heart'. Can the message-receiver resist the effect of a repeated exposure to values as seen by the handsome, lovely, loving and funny hero or heroine of the film, Mrs. Doubtfire? The Cultivation Theory doubts it, and so do I. The translation in this example is direct and so literal that the translator did not exert any effort to mediate in the target text in order to suit the target language, culture or audience. His strategy makes him visible, i.e. the subtitling reads like a translation rather than an original text.

Throughout the film, some subsidiary foreignised values can be deduced, e.g. the scene of setting the table for super, example [5] and Figure 1. The visual image here complements the sentence uttered eloquently with high etiquette manners by Mrs. Doubtfire. Linguistically, the use of the passive structure of the verb 'served' and the polite word 'madam' and, extralinguistically, the poshy way of pronunciation all show the admirable side of the British manners. The same applies to the Arabic translation.

[5]-Mrs. Doubtfire: The dinner is served madam

$$
\text { - العثاء جاهز با سيدتي }
$$

The traditional Arab way of setting the table is quite amusing. Many Arabs are used to sitting on the floor around the food or put the plates on a short round table (about 30-40 cm high). Recent communication theories in the West teach the Arab setting of tables, as such, as the best method for family communication particularly during meal times vs. the Western version which enhances non- or mis-communication.

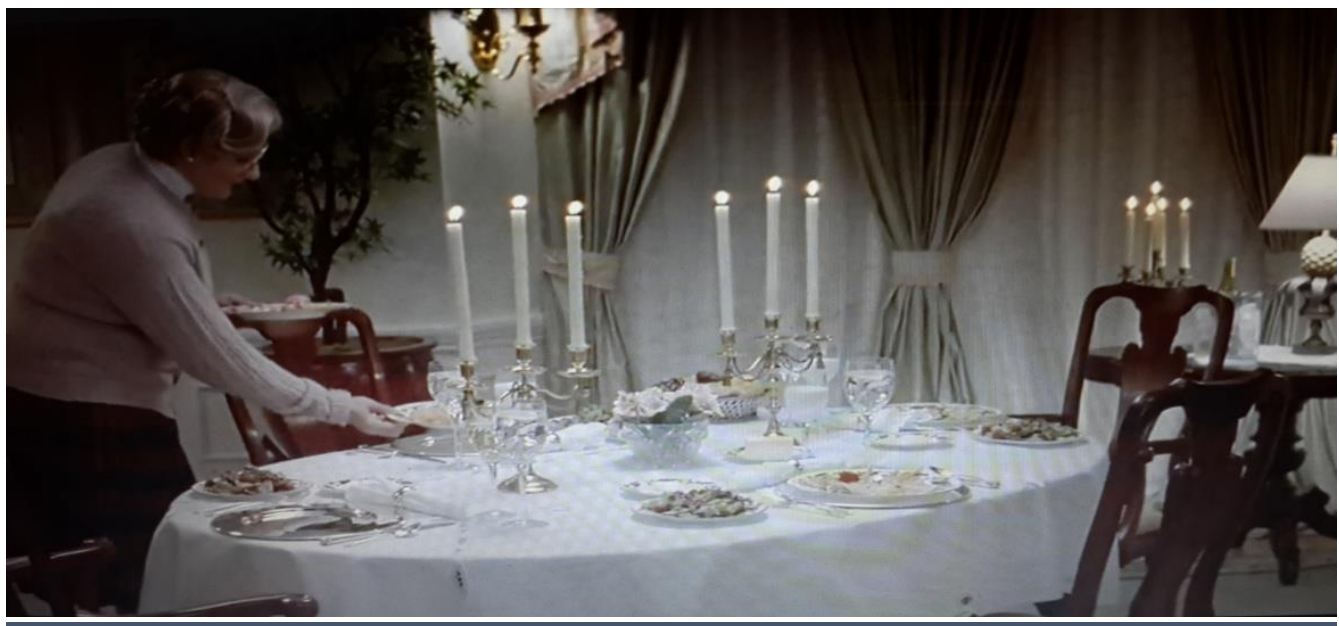

Image 1: Setting the Table for Dinner 


\section{By Dr. Safa'a Ahmed}

One big main dish in the middle in the Arab setting, vs. individual portions for each in the western setting, teaches co-operation, unity, social solidarity and helps sympathize with others since food should suffice everyone. Although very appealing and romantic, the too many decorations on the Western table (like candles, big vases and long flowers) hinder communication between the parties sitting around the table, let alone distracting them from communication. Sitting this way allows the large Arab family to fully engage into one shared topic to discuss, while the Western family members hardly talk and at best engage into various and different topics between the members sitting closer to each other. The exportation of this foreignised image of the West as the civilized and modernized ideal for table manners should attract further attention from scholars especially since similar foreignised values can thus influence the Arab society's culture and identity.

This discussion is further supported by the questionnaire results, Table 2 and Graph 2. In Question 1, 'Do you think the Arabic translation of English films in mass media has helped spread some foreignised values alien to Arab societies?': 40 females answered 'yes' and 9 males 'no', while only 1 female said 'no'. This indicates that the youths realize and recognize the problem of foreignised values flowing from the West through the translation of films into Arabic. The seemingly strange results of Question 2, 'Do you think such foreignised values negatively affected family ties?' are 27 females answered 'yes' vs. 3 males, while 14 females vs. 6 males said 'no'. This means that almost $34 \%$ of females and $66 \%$ of males do not think that such foreignised values affect negatively family relationships. Perhaps ideas like women empowerment appeal to them, instead. Question 3 asks respondents to specify how far they agree or disagree to the statement 'The Arabic translation of English films in mass media has helped in undermining family bonding and values in Arab societies'. None of the females or the males strongly agreed or strongly disagreed. 19 females vs. 2 males agreed, 20 females vs. 6 males stayed neutral. 2 females vs. 1 male disagreed. This means that about $46.3 \%$ of females agree, $48.8 \%$ neutral and $4.9 \%$ disagree i.e. they are more inclined towards being neutral and they agree generally that such values undermine family bonding and values, though indecisively. As for the males, about $22.2 \%$ agree, $66.7 \%$ neutral and $11.1 \%$ disagree. Though the number of males who agree is twofold the number of those who do not, yet the picture is neutral, indecisive, for them to a great extent. Maybe this reflects the idea of the research that such foreignized values have affected Arab youths. This needs further psychological scrutiny. 
Postcolonialism and Foreignisation as a Translation Strategy: A New

Perspective to the Arab Family Values in Translated English Films

\subsection{Wife-Husband Relationship and Roles}

Gender role-shifting is one of the most important themes in the film. It is a critical change in the structure of Arab societies, Moufeed (2015;Trans.) assures. The woman is performing the man's role and thus he is deprived of, or does not play, many of his roles. This in turn paralyses society and deforms the stereotype image of both the father and the mother. An accumulation of or an exchange in roles has taken place. The accumulation of roles appears in all the roles performed by the woman outside and inside the house so that she no longer cares about her basic roles as a mother educating and satisfying her children, particularly in the first few years, or as a wife. She has assigned the mother's role to the housekeeper, mostly unqualified, to be a substitute for her. She got her right to work, like a man; but to be the one who is responsible for the financial running of the family affairs and the man becomes jobless are the clearest evidences for role exchange. Moreover, the materialist West has been promoting the equation 'money equals authority and power' as the most important value in a family?money speaks louder than values? instead of 'love and respect equal power'.

The first appearance of Miranda at work reveals her power as an empowered, confident, elegant and decisive designer who has a successful career. Nothing can explain the idea of role-shifting better than the director's delineation of women empowerment in Image 2:

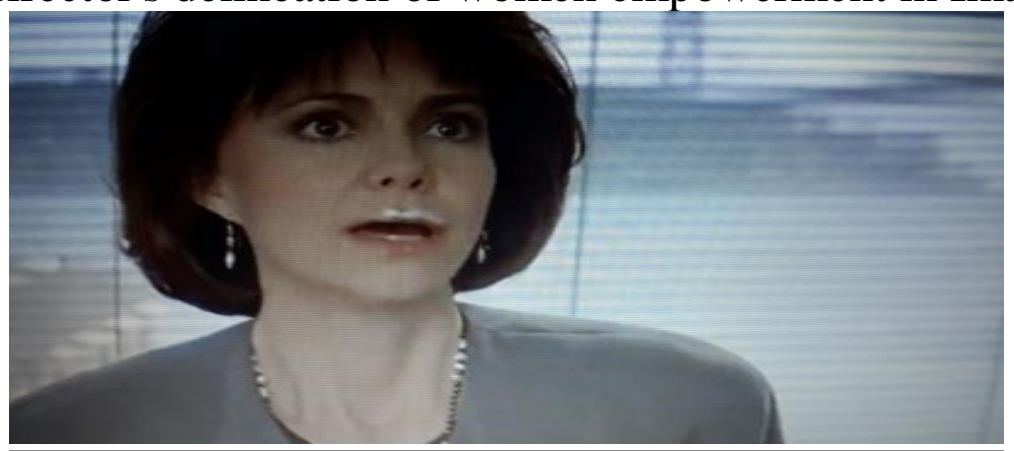

Image 2: Gender Role-shifting

Here, Miranda is sitting in her office drinking a cappuccino and a moustache is drawn by the froth. The moustache is by no means a coincidence and her boss draws her attention to it in the film.

An early scene, too, shows how far gender role-shifting can go. The father celebrates his son's birthday with a weird party where not only friends but also barnyard animals are invited to the house. Since it is illegal to possess barnyard animals in a residential area, a policeman comes to investigate a noise violation communiqué and look for the 
owner of the house. Instead of interrogating a responsible man, he talks to Miranda. In example [6], she answers the policeman's question if she is aware of such an illegal action, with a ridiculous rhetorical question mocking at and disrespecting her husband: 'What if you're married to one (animal)?':

[6]-Officer: Are you aware it's illegal to possess barnyard animals in a residential area?

\section{-Miranda: What if you're married to one?}

-Officer: We're also responding to a noise violation.

Miranda: I'm going to respond myself./ I'm awfully sorry about this.-Translation:

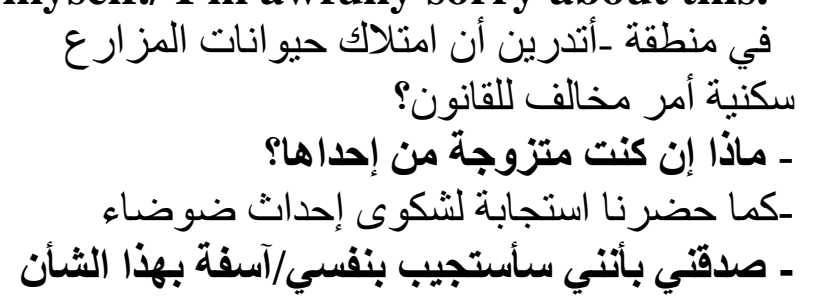

This reflects the imbalanced relationship between the wife and her husband due to role-shifting. Also the power in her sentences 'I'm going to respond myself' and 'I'm awfully sorry about this' should have been uttered by a responsible man, not a woman.

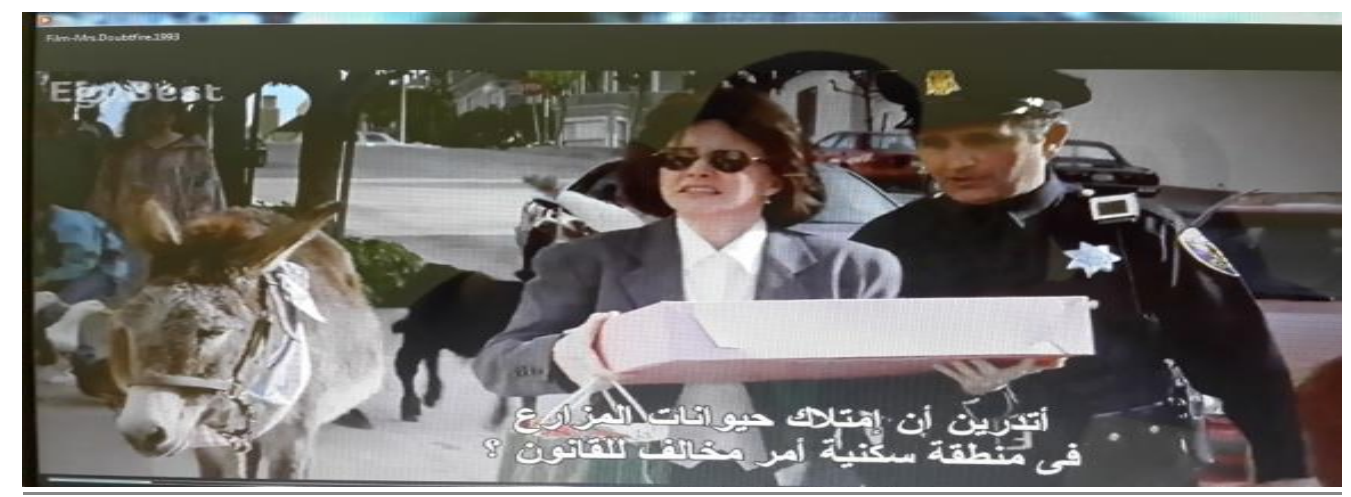

Image 3: The Empowerment of Women

Regardless of adding 'believe me' and omitting 'awfully', the target text is translated literally and it succeeded in conveying the same original message exporting in this way values alien to Arab traditions. The very idea is further enhanced through visual images. For instance, in this image Miranda is dressed up in a manly suit, looks firm, walks in decisive long steps, and carries a tart for her son's birthday. Even the way the policeman talks and reacts to her would fit a man-to-man talk instead. This image would have been normal had it replaced Miranda's face with that of a male, in this case Daniel.

The traditional Arab image of the mother as the tender, affectionate and loving one to her children vs. the father as the one who is firm, strong and responsible and who punishes if and when necessary, seems to be 
Postcolonialism and Foreignisation as a Translation Strategy: A New

Perspective to the Arab Family Values in Translated English Films

twisted, confused and shifted in the film. Therefore, in a conversation with Daniel, example [7], after she brought the party upside down the moment she had arrived home, she blames him for making her look like a 'monster', a 'heavy' person and the 'bad guy' in the family. But what she does not probably realize is that she is to blame alike. She accepted to play the role of a man and he accepted to play that of a woman:

[7]-Miranda: Don't you dare/make me out to be the monster here,

Daniel!../

Why do you always/ make me out to be the heavy?/

.. You set me up every time to be the bad guy.

$$
\begin{aligned}
& \text { إيالك أن تجرؤ يا دانييل!... لا تجعلني أبدو كالوحش هنا،/ }
\end{aligned}
$$

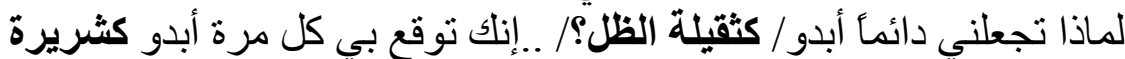

The target text introduces source culture expressions through the foreignisation strategy which the translator decided to follow from the beginning of the film. The expression 'Don't you dare!' is translated directly into Arabic without any attention to the target reader, and whether it is going to be acceptable to him linguistically and culturally or not.

Because gender roles are shifted, the husband does not look at his wife as such and vice versa. Therefore Miranda complains to Mrs. Doubtfire that 'My husband has never appreciated' her organizational skills in perfectly appointing everything in the kitchen a little cubby and a name tag. She goes on to reveal to Mrs. Doubtfire the reason why she wants divorce. Although she loved Daniel's romance, passion, energy, spontaneity and being funny, she argues, 'But after a few years, 'everything just stopped being funny' and more importantly she started to feel the pressure from her work while he was moving from one job to another for whatever reasons:

[8]-Miranda: I was working all the time./And he was always between jobs./

I hardly ever got to see the kids./If I got home early to be with them,/ something would go wrong./The house would be wrecked/ and I'd have to clean it up.

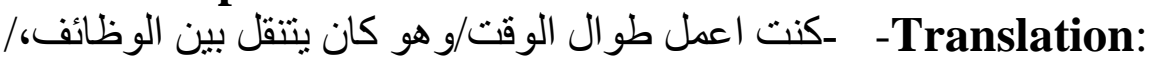

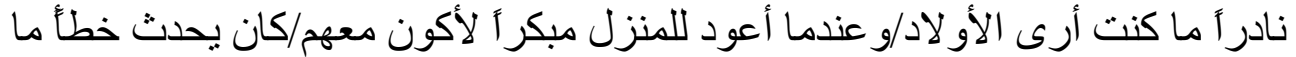

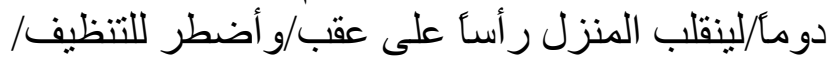


Again, she works and he does not. Gradually, she has become the performer of the role of a man ('working all the time'), forsaking consequently the role of a mother ('hardly ever got to see the kids'). As the kids get used to having no mother at home, 'if' (not 'when') she goes home early to sit with them, 'something' (any reason) goes wrong. Now because of her work stress, she often becomes unable to do any necessary clean-up at home. An inevitable question arises: is she happy with this empowerment and shift of roles? No. She says that Daniel has never known that 'so many nights I just cried myself to tears to sleep'. The translation is literal and consequently the target viewer gets the foreignised values without the least intervention on the part of the translator to keep the target identity untouched.

Other subsidiary foreignised values are introduced, meanwhile. For instance, the idea of dating a wife (though about getting divorce) is unacceptable in the Arab culture. The film presents this idea openly as a natural part of the Western culture. Daniel, dressed up in Mrs. Doubtfire, sees Miranda's lover sitting with the whole family in the house and he says to himself ridiculously:

[9]-Mrs. Doubtfire: Lover boy's here.

The translator conveyed the scene literally.

$$
\text { العانثق هن--Translation: }
$$

Question 4 of the questionnaire asks respondents to declare how far they agree to the statement 'The Arabic translation of English films in mass media has helped in undermining the husband-wife relationship and roles' (check Table 2 and Graph 2). Results show that 6 (i.e. 14.6\%) females strongly agree, $19(46.3 \%)$ agree, 12 (29.7\%) neutral, $2(4.9 \%)$ disagree and $1(2.5 \%)$ strongly disagree vs. $1(11.1 \%)$ male strongly agree, $3(33.4 \%)$ agree, $2(22.2 \%)$ neutral, 2(22.2\%) disagree and $1(11.1 \%)$ strongly disagree. This implies that generally females and males tend to agree that the wife-husband relationship and roles have been undermined. $7.4 \%$ of females vs. $33.3 \%$ of males disagree or strongly disagree. $29.7 \%$ females vs. $22.2 \%$ males remain indecisive.

\subsection{Husband-Wife Relationship and Roles}

In contrary to Miranda's stereotyped appearance of an empowered woman, Daniel seems a weak and careless father; his celebration of his son's birthday in the party scene is a good example. But he is a devoted, 'an obviously loving father' (using the Judge's words) who cannot bear the idea of being separated from his children:

[10]-Daniel: I haven't been away from 'em for more than one day since the day they were born.

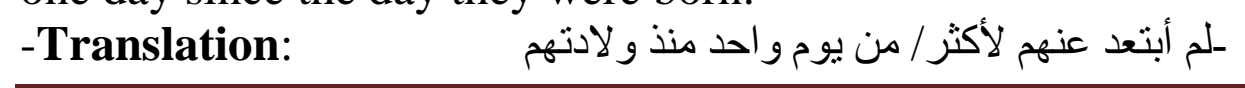


Daniel's affection, love and tenderness vs. Miranda's firmness reflects the shift in roles, the man plays the role of a mother while the woman plays the father's. The translation is almost word-for-word and it managed to convey the message to the target reader, namely how tender he is and how firm she is.

When Miranda came home during the party and 'busted' it, Daniel seemed so weak that the following dialogue between them should have been acted the other way round in normal circumstances, had it not been for gender role-shifting in the family. The contrast between the power in Miranda's sentence 'What the hell is going on around here?', example [11], and the weakness in his answer 'Don't get mad, honey. Listen.. I was gonna clean it all up before you get home' refers to the shift immediately. The translation is literal conveying the source text expressions as they are in the source language and culture, which sounds strange to the Arabic language and culture.

\section{[11]-Miranda: What the hell is going on around here?}

-Daniel: Don't get mad, honey. Listen./You're home a little early. I was gonna/clean it all up before you got home./

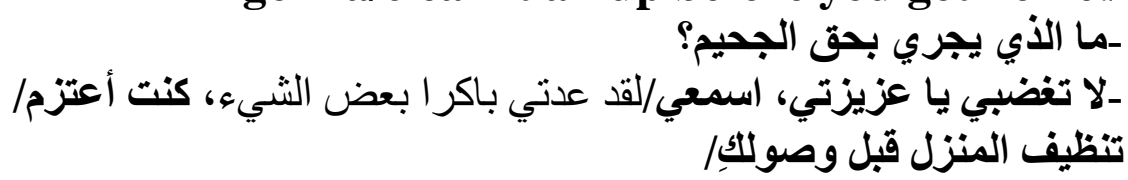

The translator thus becomes visible and foreignised values and culture creep into the consciousness and unconsciousness of target text readers.

As Miranda decides to go onto the legal process of divorce, the Judge allows Daniel to see his children only on Saturdays because he is unable to get a job and find a suitable house? again the Western materialist equations, no job equals no money equals weakness equals divorce. Miranda refuses his request to stay with his children in the house. Hence, the loving father thought to take the chance that Miranda wants a housekeeper and dresses up like a British old lady, Mrs. Doubtfire the housekeeper, as a way to see his children daily instead of a Saturday visitation.

The role of Mrs. Doutbtfire is the highlight of manifesting the theme of role-shifting. Daniel performs the role of a woman keeping the house and taking care of the kids. He cooks, vacuums, and does all the chores required typically from a mother. I do not argue, however, that a man should not do such tasks, instead there is a difference between helping and role-shifting. 


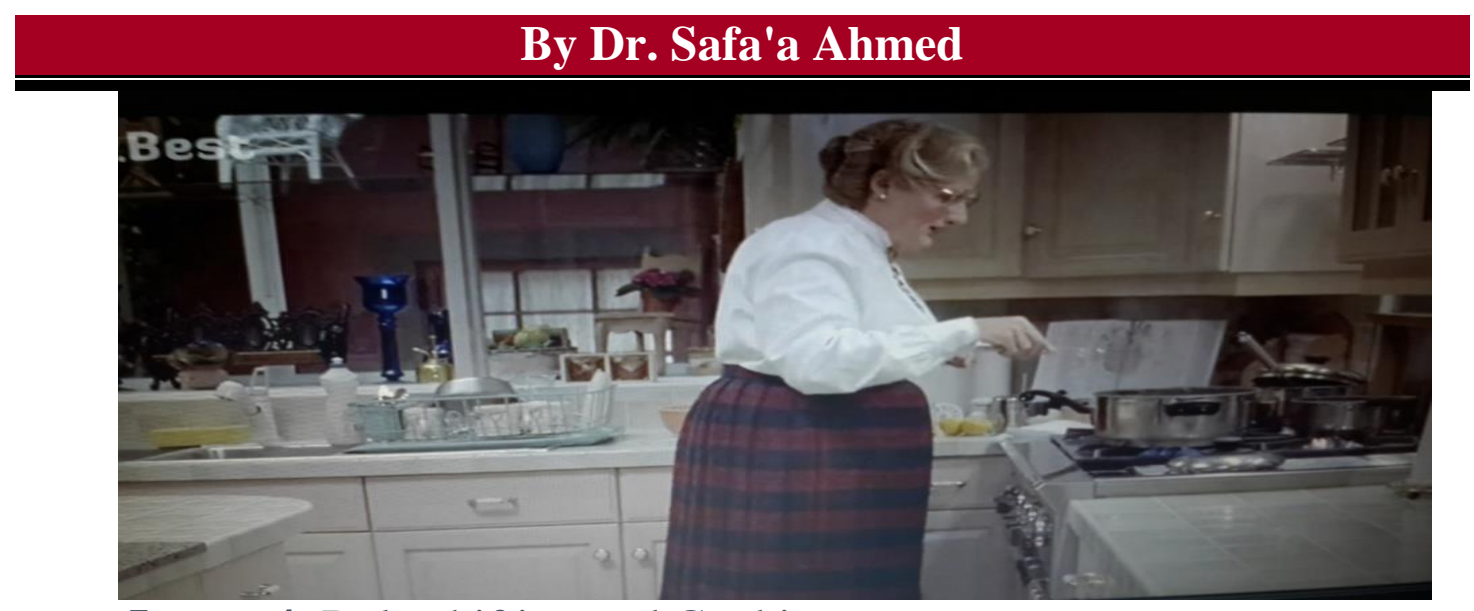

Image 4: Role-shifting and Cooking

Visual images in the film play the major part in conveying the intended message. Image 4 is very critical for it shows not only role-shifting, but also how amusing playing the role of a woman cooking may be and here lies the dilemma. The man seems to enjoy playing a woman's role. $\mathrm{He}$ dances with the broom and sings joyfully as in the broom scene, Image 5. The amusement in playing the other gender's role may invite the audience to 'imitate' Mrs. Doubtfire. Gradually due repeated exposure to these messages, the shift in roles becomes acceptable and the norm.

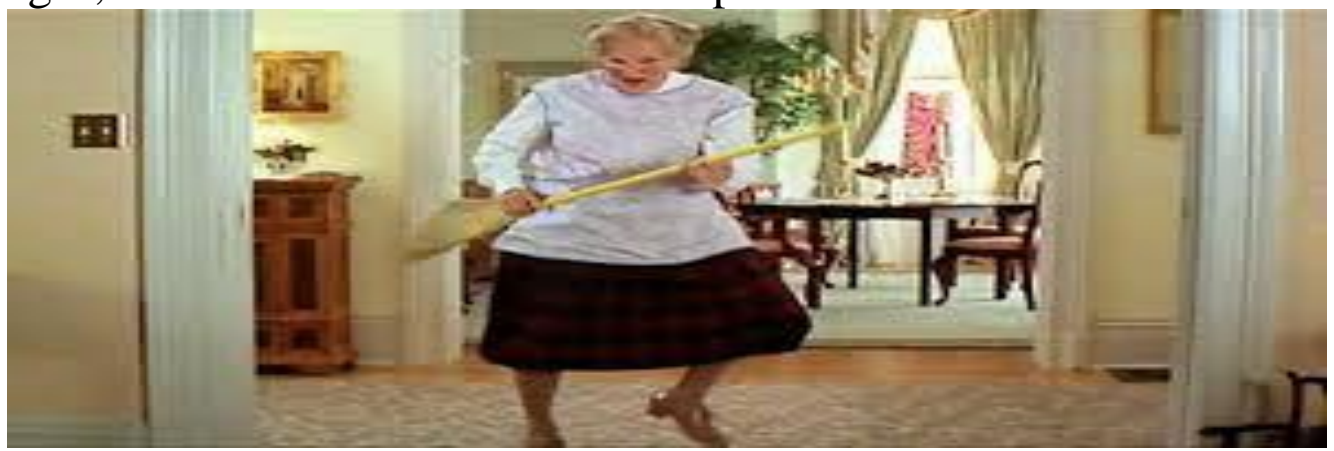

Image 5: Role-shifting and Dancing with the Broom

Yet, the character of Mrs. Doubtfire raises legal questions about deceiving people by dressing up like a woman and wearing a prosthetic mask. The Judge considers it as a clever acting by a clever actor and refuses consequently to give children custody to a 'deceiving' father whose behaviour is 'very unorthodox', 'peculiar and potentially harmful'.

Daniel sums up a major problem for a working woman playing the role of a man. Here, I am not investigating a working mother's life, instead I study role-shifting through women empowerment at work. There is a great difference between both states. He mentions in the following example that she 'chose the career' and preferred it to the kids and the husband: 
Postcolonialism and Foreignisation as a Translation Strategy: A New

Perspective to the Arab Family Values in Translated English Films

[12]-Daniel: You chose the career./ You spend too much time with/ those corporate clones you used to despise./ أنت اخترتِ العمل/.أدركي أنكِ تقضين وقتاً طويلا/ مع شركائك الذين كنتِ تمقتبنهم

With the exception of adding the word 'realize' and omitting 'used to' and 'too' from the target text (maybe due the nature of subtitling as due regard should be paid to the time and conciseness factors), the translation is literal.

Unfortunately the mother does not understand that even the most perfect house-keeper is not a substitute for her. She is so dependent on her that she refuses to let her go and replace her with the father who begs Miranda to. She assures 'I can't get rid of Mrs. Doubtfire. She's terrific' and 'She's the best thing that has ever happened to me'. This implies that she does not want a husband because she is no more a wife and that she cannot perform the mother's role, hence she will not leave her. The cornerstones of a family no more exist, then the family bond loosens and divorce becomes inevitable.

Respondents reacted to Question 5, 'How far do you agree or disagree to the statement 'The Arabic translation of English films in mass media has helped in undermining the husband- wife relationship and roles'? as shown in Table 3 and Graph 3. Out of 41 females, 5 (12.2\%) strongly agree, 15 (36.6\%) agree, $16(39 \%)$ neutral, 5 (15.2\%) disagree and none strongly disagrees vs. none of the males strongly agrees, 3 (33.3\%) agree, $1(11.1 \%)$ neutral, $4(44.5 \%)$ disagree and $1(11.1 \%)$ strongly disagrees. This indicates that $48.8 \%$ of females tend to agree generally that the translation of films has helped undermine the husband-wife relationship, while $39 \%$ remain indecisive and few disagree. On the other hand, the males' results in this regard tend to be disappointing as $55.6 \%$ disagree and strongly disagree and $11.1 \%$ remain indecisive. Of course, the small number of the males in the random sample may not reflect the young males' true understanding of the reality of mass media effects on society values.

\subsection{Parents-Kids Relationship and Roles}

In a family where there is a role-shifting between the parents, one expects the various intra- and inter-relationships between the member to be deformed in a way or another. For instance, the father mocks at the mother with the kids to the point that the 5-year-old child imagined that her father wishes the mother to die, example [13]. In this critical extract, Daniel describes the mother as an 'old battle-axe'? how would the children love and respect their mother thus? Then he says he does not like 
to see her inflicted with amoebic dysentery or piles. The son gets excited at the expression and starts informing his little sister about this dangerous disease with a lot of exaggeration ('graphic') and amusement, which is not how children should talk about a parent in his/her absence, let alone in the other's presence:

[13]-Daniel: How is the old battle-axe?/ Your mom.

-Chris: She's fine.

-Daniel: Oh. I'm glad to hear that./ I'd hate to think that she came down/ with amoebic dysentery or piles.

-Natalie: What's amoebic dysentery?

-Chris: It's an infection in your tummy/ where you get diarrhea forever.

-Natalie: Diarrhea forever?

-Chris: And your body dries up and you die.

-Natalie: You die?

-Lydia: You don't have to be so graphic with her.

-Chris: I read about it in a science book.

-Natalie: Why would you want Mommy to die?

-Daniel: Oh, honey, I don't want Mommy to die. -ما أخبار فأس المعارك الكبيرةٌ/أعني أمكم/

$$
\begin{aligned}
& \text {.أكره أن أظنها قد أصيبث/ بزحار اميبي أو باسور/. }
\end{aligned}
$$

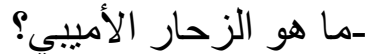

$$
\begin{aligned}
& \text { ـإإنه نوع من العدوى يصيب معدتك/ بحيث تصابين بإسهال إلى الأبد }
\end{aligned}
$$

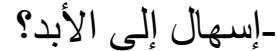

$$
\begin{aligned}
& \text { ـأجل، ويجف جسمك و تموتين الابد }
\end{aligned}
$$

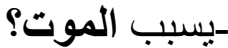

$$
\begin{aligned}
& \text { ـلا موجب لأن تكون معها تصويرياً لهذه الدرجة }
\end{aligned}
$$

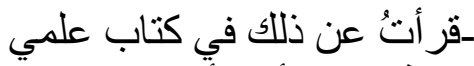

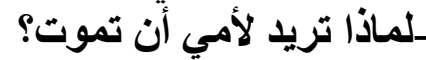

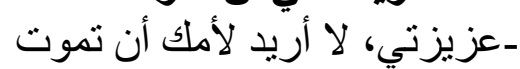

This literal translation conveyed this message as intended. But it is full of values alien to the long-held Arab traditions regarding the way parents deal with their kids and vice versa.

Miranda's misunderstanding of her role as a mother and a wife leads her to believe, even unconsciously, that the children are her own and not the father's since he does not play his role, willingly or unwillingly.

[14]-Miranda: Are my children ready yet?

-Daniel: No, our children are not ready yet...

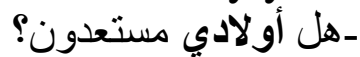
ـالا، أولادنا ليسو ا مستعدون بعد.. 
Postcolonialism and Foreignisation as a Translation Strategy: A New

Perspective to the Arab Family Values in Translated English Films

Daniel corrects her and draws her attention to the phrase 'our children' instead of 'my children'. The translator rendered the text literally with the same form and content.

Parents are models for their kids. Using inappropriate, curse language would be the last thing parents should teach their children:

[15]-Daniel: you're my damn kids too!

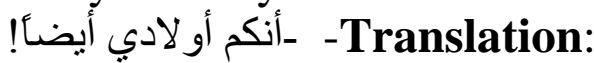

Daniel talks to his children using words like 'damn' in [15]. Though the translator followed a literal translation strategy consistently all along the film, he omitted 'damn' from the target text. I do not think he did so for reasons related to appropriateness to the Arab reader because in the next example he simply translated it into Arabic. When Daniel proposes to take the children from their school and keep them for a couple of hours until Miranda is back from work, instead of having a housekeeper, she refuses. Both him and the kids get disappointed and the youngest child says to her mother:

\section{- - - - - - Translation:}

[16]-Natalie: We're his damn kids, too

This means that children imitate their parents and they will similarly repeat the inappropriate expressions they heard from them. This translation strategy, foreignisation, introduces such westernized expressions into the Arabic culture.

Mrs. Doubtfire draws Miranda's attention to something important for proper, healthy family relations especially for children; parents should not criticize each other in front of their children. So, she asks her not to start to 'verbally bash their father' unless they get out of the room:

\section{[17 ] I'm sure you'd want the children} to step out of the room

before you verbally bash their father. Hm?

-Translation:

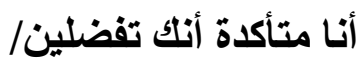
خروج الأولاد من الغرفة/ قبل انتقادك لو الدهم حرفياً

Family bonding necessitates that each member should know his rights and duties towards the others. The more they respect values, the stronger the bond becomes. Divorce can be considered one of the results of disrespecting parents. Although Mrs. Doubtfire shows Miranda, and of course the viewer, how to behave, in an attempt from the disguised father to rescue his family from the destiny of separation, this comes very late. The translator is visible in this example due to his literal strategy. He 


\section{By Dr. Safa'a Ahmed}

translated word-for-word, particularly the word 'verbally', which sounds linguistically and semantically absurd to the target audience.

Question 6 asks respondents to choose how far they agree to the statement 'The Arabic translation of English films in mass media has helped in undermining the parents-kids relationship and roles' (refer to Table 3 and Graph 3). 1 (2.5\%) female strongly agrees, 13 (31.7\%) agree, $11(26.8 \%)$ neutral, $14(34.1 \%)$ disagree and 2(4.9\%) strongly disagree vs. $1(11.1 \%)$ male strongly agrees, $2(22.2 \%)$ agree, $2(22.2 \%)$ neutral, 1 (11.1\%) disagrees and $3(33.4 \%)$ strongly disagree. This means that about $34.2 \%$ of females generally agree that the translation of films has undermined the parents- kids relationship, 39\% disagree while $26.8 \%$ preferred to be neutral. This may be accounted in the light of the various advantages they get from the Western parents in regard to dealing with their kids; they may admire the West. The same applies to the males of whom $33.3 \%$ agree, $44.5 \%$ disagree while $22.2 \%$ remained neutral.

\subsection{Kids-Parents Relationships and Roles}

Among the foreignised values introduced through the film and its translation is how kids deal with their parents and their own sisters and brothers. Daniel's eldest child, Ldyia, talks 'freely' (from her opinion), 'impolitely' (from the Arab traditions stand) to her father. In [18], she asks her father 'You mean you got fired?' as if she is taking to a friend. Then she is unashamed of describing him as an 'actor', implicitly 'a liar'. The

\section{[18]-Lydia: You mean you got fired?}

-Daniel: No, I quit. For reasons of conscience.

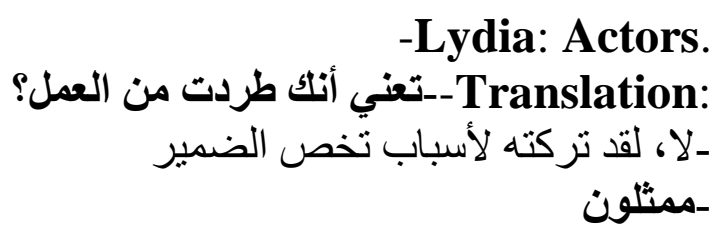

Arabic subtitles, a direct translation from the source, definitely convey this idea so bluntly to the Arab audience, which seems to appeal to the children. Who does not like all restrictions to be lifted from his shoulders?

This is how translation introduces ideas and values alien to the target culture and identity. Too much 'freedom' to do whatever you like wherever you like without any boundaries or restrictions, be them values, traditions, religion, etc. creeps into the more conservative Arab culture under allegations of modernization and globalization. In [19], Daniel tells his son that he has a surprise for his birthday party; the boy, whom he calls 'dude', is excited to have a 'stripper' as a present. When the father says 'Ooh, please', he moves one step further and thinks of 'two strippers'. 
Postcolonialism and Foreignisation as a Translation Strategy: A New

Perspective to the Arab Family Values in Translated English Films

[19]-Daniel: Dude, congratulations/on your 12 birthday. Got a surprise for ya.

-Chris: A stripper?

-Daniel: Ooh, please!

-Chris: Two strippers?

-Daniel: Hoo-hah, boy!

-Translation: يا صاح، تهانينافي عيد ميلادك الثاني عشر/لاي مفاجأة للك

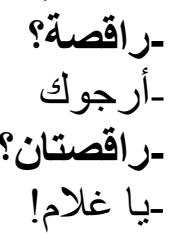

Indeed, still in many parts of the Arab World, the target audience can hardly accept this kind of open conversation. Again the literal translation presents the message plainly without the least mediation from the translator to save the face of the audience. The translation is so direct that the translator seems to have opened the dictionary and written down the first Arabic word he saw for 'dude'. The translation reads archaic and arcane, rather than equivalent.

Closely related to that idea is the flagrant honesty of the kids to the extent of being rude with parents. For instance, Daniel invited his kids to an apartment he is preparing to invite them to drop in sometimes during Saturday visitation. When asked how far she likes it, Lydia says her opinion, 'detestable', with the least regard to her father's feelings.

[20]-Daniel: I know the place/doesn't look like much now, but.../ It'll be OK. How do you like it?

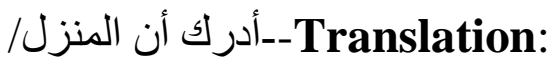

-Lydia: Detestable.

لا يبدو ملائماً حالياً، ولكن../ألكنه سيغدو على ما ير ام،/ما رأيكم به؟

- بغيض بـ

Repeated exposure to such messages in the media makes these scenes normal to the viewer and thus shapes their knowledge of the world. Also the translation conveys the original messages as they are through the use of foreignisation as a translation strategy introducing values alien to the target language, culture and reader.

The film shows the kids taking the opportunity of being home alone with none or one of the parents to act against the rules. Daniel helps them break the rules and celebrate the birthday with a 'wild kingdom' since 'Mom's not gonna be home' for a few hours, example [21]. Though these situations might seem trivial in comparison to larger themes such as 
gender role-shifting, they build up and cause fissures in the structure of the family.

[21]Daniel: Mom's not gonna be/ home for another four hours, is she?/

Prepare yourself... for the wild kingdom.

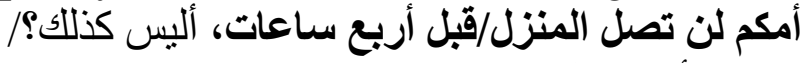

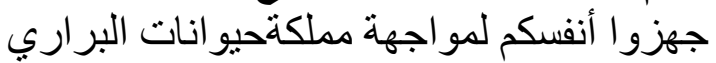

What is dangerous in introducing the Western way of living as the modernized one while the Other's underdeveloped and uncivilized, is that it washes brains and changes the identity of the Other gradually. Translation plays an undeniable role in making ideas accessible to other audiences on the other side of the world.

Question 7 invites respondents to identify how far they agree or disagree to the statement 'The Arabic translation of English films in mass media has helped in undermining the kids-parents relationship and roles'. $6(14.6 \%)$ females strongly agree, $23(56.1 \%)$ agree, $7(17.1 \%)$ neutral, 5 $(12.2 \%)$ disagree and none (0\%) strongly agrees vs. none of the males strongly agrees, $7(77.8 \%)$ agree, none $(0 \%)$ neutral, 2(22.2\%) disagree and none (0\%) strongly disagrees (refer to Table 3 and Graph 3). This means that $70.7 \%$ of the females generally agree that translation of films has undermined the kids-parents relationship, while $17 \%$ remained neutral. The same applies to males who agreed to the statement with a percentage of 77.8 and none was neutral. These results astonished me because I expected them to disagree since the idea of freedom in dealing with parents might look appealing to them. However, they agreed, which reflects their understanding of the inappropriateness of the kids-parents relation as presented by the West.

\subsection{Kids-Kids Relationships and Roles}

Family bonding suffers from the beginning of the film due to the unbalanced relationships between the various family members. If all the above-mentioned relationships have a problem, then it is expected that the kids-kids relationship has an issue too. Lydia, the elder sister, disappoints her brother who is very excited for his birthday celebration telling him 'No. No parties', [22]. The reference to 'your report card' also arouse hard feelings between them. This offish mood definitely puts kids off. The structure of the Arabic translation sounds awkward because the translator used a word-for-word strategy, and so does the literal translation of expressions like 'your record card'. 
Postcolonialism and Foreignisation as a Translation Strategy: A New

Perspective to the Arab Family Values in Translated English Films

[22]-Lydia: No. No parties./Mom said you couldn't have one/

because of your report card.

-Translation: - الا.. لا حفلة/قالت أمي بأنه لا حفلةلك/ بسبب سجل علاماتكال

The translator might have preferred a literal translation to a semantic, cultural one that suits the target language, culture and reader since the former seems more faithful to the source speaker and original message. But in his attempt to be faithful to the source language and culture, he turns to be unfaithful to the target language, culture and reader.

The film introduces a strange value here, being submissive to and accepting the idea of injustice. Why should all the kids be punished for a fault made by one of them? When Lydia talked inappropriately to Mrs. Doubtfire, all of them were asked to clean the house. This breeds hatred to the whole society. Therefore, the younger sister and brother shout at their elder sister 'shut up', 'You got us into it' (example [23]), when the latter asks them not to listen to the housekeeper. Respecting the elder brother or sister is an important value necessary for a strong kids-kids relationship and a solid fortified family bond.

[23]-Natalie: Shut up, Lydie.

-Chris: Yeah. You got us into this.

-Translation:

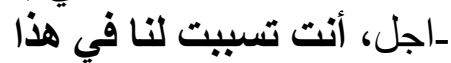

Unfortunately this kind of conversation is conveyed through a verbatim translation of the original; it renders the message and even the way of expression directly into the target culture and educates the viewer about how kids deal with each other. So long as repeated exposure to messages in the media affects the viewer, according to the Cultivation Theory, then the danger implicit in such a translated message becomes evident.

Question 8 invites respondents to specify the degree of agreement or disagreement to the statement 'The Arabic translation of English films in mass media has helped in undermining the kids-kids relationship and roles'. $10(24.4 \%)$ females strongly agree, 18 (43.9\%) agree, 9 (22\%) neutral, $3(7.3 \%)$ disagree and $1(2.4 \%)$ strongly disagrees vs. $3(33.4 \%)$ males strongly agree, 2 (22.2\%) agrees, 2 (22.2) neutral, 2 (22.2\%) disagrees and none $(0 \%)$ disagrees. This means both females and males generally agree to the statement with a percentage of 68.3 and 55.6 respectively with about $22 \%$ of both remained neutral.

After respondents had answered all the previous questions evaluating the different family relationships from a translation and mass 


\section{By Dr. Safa'a Ahmed}

communication perspective, they answered the open-ended question where they were asked to write their opinion on how to make the role of translation more positive when it comes to the translation of films from English into Arabic (refer to Table 4 and Graph 4). 19 respondents mentioned that the translations of films which negatively affect Arab culture should be avoided. 5 said that the translation of curse or inappropriate words should be avoided. 2 suggested translating using a domestication strategy instead of foreignisation. 3 put the blame on families themselves. 2 suggested that it is not the translator's role or responsibility. 4 referred to how translation introduces a good foreign culture. 3 explained that translation is both positive and negative. 2 pointed out that translators should be honest. 1 indicated that mass media should become a model. 6 gave an irrelevant response. 3 wrote no comment. This means that $38 \%$ of respondents suggested to avoid translating the films which carry negative or foreignised values to the Arab culture, a result I totally agree to. Also $10 \%$ proposed to avoid the translation of curse and inappropriate words. In other words, avoiding translation in their opinion is the most important action to be taken in case a film presents any ideas which can deform the family values of the target audience.

\section{Conclusion}

To sum up, this paper had as its aims the investigation of postcolonialism and the use of 'foreignisation' as a translation strategy in mass media and the exploration of the latter's role in introducing some foreignised family values and roles alien to the identity of Arab societies not only from a translation perspective but also from a mass communication one. From this aim, I set some objectives in order to answer three questions. First, what is the role played by the translation of English films in mass media in introducing some foreignised values alien to the Arab families bonding and values? Second, how can foreignisation as a translation strategy suggested by postcolonialists to resist colonialism, contribute itself to viewers' conceptions or misconceptions of social reality? Third, what do the Arab youths think of this role? The analysis was based on both qualitative and quantitative data derived from an English film and its Arabic translation, and a questionnaire respectively. It was supplemented with some visual images. Despite the limitations of the study explained in the methodology section, I was able to draw some conclusions.

The analysis and discussion of data and results reveal that contrary to what many postcolonial advocates claim that the translator should adopt a foreignisation strategy, it enhances colonialism, or neocolonialism, when 
used in the translation of English texts into Arabic, or into what they call the 'less hegemonic languages' (borrowing their own terms). In fact, Niranjana proposes 'foreignisation' as a 'postcolonial' translation strategy from Third World languages into English, so the translated works in this case would reflect the culture and identity of these nations. Yet, when it comes to translating from a hegemonic language, such as English, into a Third World's, then foreignisation can be dysfunctional.

The translator might have preferred a literal translation to a semantic, cultural one that suits the target language, culture and reader under the belief that the former is more faithful to the source speaker and original message. But his faithfulness to the source text/ speaker, language and culture should have been replaced by faithfulness to the target reader/ viewer, language, culture and identity. His translation strategy introduced foreignised values alien to the Arabic language and the Arab culture and reader, a matter which negatively affects family bonding and values. 'Family', gender role-shifting, and divorce were the major themes of the film, through which foreignised values were presented as the modernized, civilized, globalised and acceptable versions $\mathrm{f}$ values. That is to say, the translation strategy used together with mass media (since repeated exposure to such messages influences the viewer's conceptions or misconceptions about the world, according to the Cultivation Theory) have challenged and undermined some of the Arab family values and roles.

The results of the questionnaire were quite amusing. Both females and males generally agree that the translation of English films has helped spread foreignised values. But they generally tended to disagree that such translations negatively affected family bonding and values: $34 \%$ females vs. $66 \%$ Males. Whereas the respondents were inclined towards being neutral, indecisive, regarding the degree of agreement or disagreement to the statement that the translation of English films has undermined family bonding and values: $48.8 \%$ females vs. $66.7 \%$ males. They both generally agree that this has undermined the wife-husband relationship. While females $(48.8 \%)$ generally agree that those translations have undermined the husband-wife relationship, 55.6\% of males disagree (they might have thought of the issue comparing the harsh way Arabs used to deal with their wives vs. the flexible 'idealized' way presented through the Western point of view). The respondents seem to enjoy the fruits of Western freedom and therefore they generally disagree that translations have undermined the parents-kids relationship. Yet they generally agree that such ideas have undermined the kids-parents relationship, touching 
perhaps how rude kids deal with their parents. They also generally agree that kids-kids relationship have been undermined.

The study recommends the following:

1-The long-held, arcane and archaic definition of 'translation' and 'foreignisation' as a translation strategy should be reconsidered.

2- English mass media materials, especially films, should be filtered before translating them into Arabic. Whatever introduces values alien to Arab families and values should not be translated.

3- Whenever a certain material would be translated, the translator should domesticate the target text to suit local traditions and values.

4- Postcolonialists should revise the tenets of their theory.

5-Eurocentricsm in translation studies should be confronted by Arab

scholars' and theorists' writings from their identity perspective.

6- The 'role' of mass media in a globalised world should be redefined. 


\section{References}

Al-Qawasmi, Hamzah. (n.d.). Aham Al-Awamel Al-Moathera Ala Al-Osrah. Retrieved from https://sites.google.com/site/tersting12/home/hamzah in October 2108.

Ashcroft, B., Griffiths, G. and Tiffin, H. (1989).The Empire Writes back: Theory and Practice in Post-colonial Literatures. London: Routledge.

Bartley, W.W.III (ed.) (1989). The Collected Works of F.A. Hayek: Volume I The Fatal Conceit: The Errors of Socialism. Chicago: University of Chicago Press.

Basu, B. (2014). Postcolonial World Literature: Forster-Roy-Morrison. The Comparatist, 38(1), 158-187.

Bhabha, H. K. (1994). The Location of Culture. London: Routledge.

Bauman, Zygmunt (2015). Defining the Family, posted 8 August 2015, Retrieved from https://revisesociology.com/2016/08/08/defining-the-family/ October 2018.

CyperParent. (2017). How Do You Define Family? The True Meaning Of Family. Posted 1 November 2017. Retrieved from https:// cyberparent.com/relationships/define-family-true-meaning-family/

Dharwadker, Vinay. (1999). A.K. Rananujan's Theory and Practice of Translation. In: Post-colonial Translation, Susan Bassnett and Harish Trivedi

Garane, J. (2014). How Postcolonial Translation Theory Transforms Francophone African Studies. The Comparatist, 38(1), 188-205.

Gerbner, George (2002). Advancing on the Path of Righteousness. In Michael Morgan (ed.) Against the Mainstream.. Peter Lang Publishing, Inc., New York. pp.214-224.

Glueck, Sheldon. (1960). Ten Years of Unraveling Juvenile Delinquency, Journal of Criminal Law, Criminology \& Police Science, 51(3), pp.283-308.

Goff, Barbara. (2014). Postcolonial Translation: Theory and Practice. In Encyclopedia of Ancient Greek Language and Linguistics. Brill: Leiden. pp.122-125. Retrieved from http://centaureading.ac.uk/37983/

Gopal, Priyamvada. (1993). Sitting Translation: History, Post-structuralism and the Colonial Context (review). MFS Modern Fiction Studies, Johns Hopkins University Press, Volume 39 (1), Spring, pp. 204-206.

Haralambos, M. and Holborm, M. (2000). Sociology: Themes and Respectives ( $5^{\text {th }}$ ed.). London: Collins Education.

Haviland, A. (2002). Cultural Anthropology (10 ${ }^{\text {th }}$ edition). Belmont, Calif: Wadsworth/Thomson Learning (Electronic Source). Retrieved from https://trove.nla.gov.au/version / 49201303.

Holmstrom, Lakshmi. (1997). Issues in Translation. In: Kavya Bharati (Translation Issue), No.9, pp.1-10.

Horwitz, Steven. (2005). Two Worlds at Once: Rand, Hayek, and the Ethics of the Micro- and Macro-cosmos .The Journal of Ayn Rand Studies 6, no. 2 (Spring 2005): 375-403. 


\section{By Dr. Safa'a Ahmed}

How Do You Define Family? The True Meaning of Family. (2017). Cyperparent, 1 November 2017. Retrieved from /http://cyperparent.com/ relationships/define-family-true-meaning-family.

Ibrahim, S., Abbasi, M.H., Adnan, Ayesha and Bhatti, W. (2010). Cognition and Impact of Modernization in changing Normative structure of Family System (A Case Study). International Journal of Business and Social Science, Vol.2 No.14 (August 2010), pp.271-77.

Johnson, H.M. (2013). Sociology: A Systematic Introduction. New Delhi: Routledge.

Kress, Gunther and van Leeuven, Theo. (1996). Reading Images: The Grammar of Visual Design. London: Routledge.

Leslie, G.R., Larson, R.F. and Gorman, H.L. (1994). Introducing Sociology. Oxford: Oxford UN Press.

Leung, Matthew Wing-Kwong. (2006). The ideological turn in translation studies. In Duarte, J. F., Rosa, A. A., and Seruya, T. (eds.), Translation Studies at the Interface of Disciplines. Amsterdam: John Benjamins Publishing. pp. 129-144.

Machin, David. (2007). Introduction to Multimodal Analysis. London: Arnold.

Mayr, Andrea .(2012). Multimodal Critical Discourse Analysis. Semiotix, 3, 2012. Retrieved from http//semioticon.com/semiotix/2012/03/multimodalcritical-discourse-analysis/

Milton, John. (2008). Foreignization: A Discussion of Theoretical and Practical Issues. In Yearbook of Comparative and General Literature (Published by University of Toronto Press), Volume 54, pp. 103-113.

Mondal, Puja. (2018). The Meaning and Functions of Social Values | Sociology. Retrieved from http://www.yourarticlelibrary.com/sociology/themeaning-and-functions-of-social-values-sociology/8522

Mosharafa, Eman. (2015). All You Need to Know about: The Cultivation Theory. Global Journal of Human-Social Science: Arts \& HumanitiesPsychology. Vol.15(8), Version 1, pp.22-37.

Moufeed, Khadija. (14 July 2015). Mohadhadarat Al-Osrah wa Tahawolat AlQyam. Retrieved from http://alislah.ma

Munday, J. (2016). Introducing Translation Studies: theories and applications. ( $4^{\text {th }}$ ed.) London: Routledge.

Murdock, G.P. (1949). Social structure. New York: The MacMillan Company. Retrieved from http://euromentor.ucdc.ro/2012/vol3n22012/en/12 thesocial-functions-of-the-family. pdf

Naudé, J.A. (2012). The Shaping Of Cultural Knowledge In South African Translation. Stellenbosch pap. Linguist (36), 35-57.

Newmark, Peter. (1981). Approaches to Translation. Oxford and New York: Pergamon. Republished 2001 by Shanghai Foreign Language Education Press.

Niranjana, Tejaswini (1992). Sitting Translation: History, Post-structuralism, and the Colonial Context. Berkeley, California and Oxford: University of California Press. 
Postcolonialism and Foreignisation as a Translation Strategy: A New

Perspective to the Arab Family Values in Translated English Films

O'Halloran, Kay L. (2012). Systemic Functional-Multimodal Discourse Analysis (SF-MDA): Constructing Ideational Meaning Using Language and Visual Imagery. Visual Communication, 7, pp.443-75. DOI:10.1177/1470357208096 210.

Palakeel, Thomas. (1996). Third World Short Story as National Allegory. Journal of Modern Literature, XX, I, 1996, pp.97-102.

Parks, Alisha B. (2013). The Effects of Family Structure on Juvenile Delinquency. [Thesis]. Electronic Theses and Dissertations. Paper 2279. http://dc.etsu.edu/etd/2279

Pettersson, B. (1999). The postcolonial turn in literary translation studies: Theoretical frameworks reviewed. Canadian Aesthetics Journal, 4.

Robinson, Douglas. (1997a). Tejaswini Niranjana, Retranslation, and the Problem of Foreignism. In Trad Term, 4(2), pp. 149-165.

------ .(1997b). What is Translation? Ohio: Kent State University.

Sakellariou, P. (2011). Translation, Interpretation and Intercultural Communication. The Journal of Specialized Translation, (15), 229-246.

Schleiermacher, F. (1813/2012) 'On the different methods of translating'. In Lawrence Venuti (ed.), (2012), The Translation Studies Reader ( ${ }^{\text {rd }}$ edition). London and New York: Routledge. pp. 43-63.

Spivak, Gayatri Chakravorty. (2012). The Politics of Translation. In Venuti, L. (Ed.), The Translation Studies Reader. (3rd ed.). London: Routledge. pp. 312-330.

Trivedi, Harish. (2003). Post-Colonial Translation: Theory and Practice. Berkeley and Los Angeles: University of California Press.

------- . (2005). Translating Culture vs. Cultural Translation. 91 st Meridian, $4(1), 1-8$.

van Leeuven, Theo. (1996). The Representation of Social Actors. In Carmen Rosa Caldas-Coulthard and Malcolm Coulthard (eds.), Texts and Practices: Readings in Critical Discourse Analysis. London: Routledge. pp.32-70.

Venuti, Lawrence. (2008). The Translator's Invisibility ( $2^{\text {nd }}$ ed). London: Routledge.

----- (ed.). (2012). The Translation Studies Reader (3 ${ }^{\text {rd }}$ edition). London and New York: Routledge.

Wodak, Ruth and Meyer, M. (eds.). (2001). Methods of Critical Discourse Analysis. London: Sage.

Worsley, Peter. (1970). Introducing Sociology. Harmondsworth: Penguine Books.

Zaixi, Tan and Lu, Shao. (2007). Translation and the Relativity of Cultural Identities. Neohelicon, Volume 34 (1), pp 197-216.

\section{Source of data}

Mrs Doubtfire. (1993). Retrieved from https://egy.best/movie/mrs-doubtfire1993/ 


\section{By Dr. Safa'a Ahmed}

\section{Appendix}

\section{Questionnaire}

This questionnaire is a part of a study on the role of translating English films in introducing some foreignised family values alien to the identity of Arab societies. It aims to investigate 'postcolonialism' and the use of 'foreignisation' as a translation strategy in mass media and explore the latter's role in introducing some foreignised family values and roles peculiar to the Arabs. The privacy and confidentiality of the information provided in the questionnaire is totally guaranteed.

operation and support

Thank you for your co-

Dr Safa'a Ahmed

Languages, MSA University

The researcher:

Faculty of

Demographic Information

Name (optional):

Age:

Sex: Male

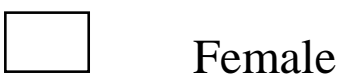

1. Do you think the Arabic translation of English films in mass media has helped spread some foreignised values alien to Arab societies?

Yes

2. Do you think such foreignised values negatively affected family ties?

Yes

How far do you agree with the following statements? Choose one answer from 1-5:

3- The Arabic translation of English films in mass media has helped in undermining family bonding and values in Arab societies.

1. Strongly agree $\quad 2$. Agree $\quad 3$. Neutral $\quad$. Disagree 5.

Strongly Disagree

4- The Arabic translation of English films in mass media has helped in undermining the wife-husband relationship and roles.
1. Strongly agree
2. Agree
3. Neutral
4. Disagree
5.

Strongly Disagree 


\section{Postcolonialism and Foreignisation as a Translation Strategy: A New Perspective to the Arab Family Values in Translated English Films}

5- The Arabic translation of English films in mass media has helped in undermining the husband- wife relationship and roles.
1. Strongly agree
2. Agree
3. Neutral
4. Disagree
5.
Strongly Disagree

6- The Arabic translation of English films in mass media has helped in undermining the parents-kids relationship and roles.
1. Strongly agree
2. Agree
3. Neutral
4. Disagree
5.
Strongly Disagree

7- The Arabic translation of English films in mass media has helped in undermining the kids-parents relationship and roles.
1. Strongly agree
2. Agree
3. Neutral
4. Disagree
5.
Strongly Disagree

8- The Arabic translation of English films in mass media has helped in undermining the kids-kids relationship and roles.
1. Strongly agree
2. Agree
3. Neutral
4. Disagree
5.
Strongly Disagree

9-In your opinion, how can mass media translation play a positive role in making family ties stronger? 